\title{
RESISTÊNCIA TÉRMICA DE ESPOROS DE Bacillus cereus IAL 2599 FRENTE A VAPOR SUPERAQUECIDO COM ATIVIDADE DE ÁGUA MENOR QUE 1,0
}

\section{DANIEL MARIO TAPIA TAPIA}

Engenheiro Agrônomo

Oricntador: Prof. Dr. LuIZ GONZAGA DO PRADO FILHO

\begin{abstract}
Dissertação apresentada à Escola Superior de Agricultura "Luiz de Queiroz", da Universidade de São Paulo, para a obtenção do título de Mestre em Ciências, Área de concentração: Ciência e Tecnologia de Alimentos.
\end{abstract}

PIRACI C A B A

Estado de São Paulo - Brasil

Agosto - 1997 


\section{DIVISÃo DE BIBLIOTECA E DOCUMENTAÇÃo - Campus "Luiz de Queiroz"/USP}

\section{Tapia Tapia, Daniel Mario}

Resistência térnica de esporos de Bacillus cereus IAL 2599 frente a vapor superaquecido com atividade de água menor que 1,0 / Daniel Mario Tapia Tapia. - Piracicaba, 1997

$70 \mathrm{p}$.

Dissertação (mestrado) - - Escola Superior de Agricultura Luiz de Queiroz, 1997.

Bibliografia

1. Bactéria patogênica 2. Esporo 3. Microbiologia aplicada 4. Resistência Térmica 5. Tecnologia de Alimento 6. Tratamento térmico 7. Vapor de água 1. Título 
RESISTÊNCIA TÉRMICA DE ESPOROS DE Bacillus cereus IAL 2599 FRENTE A VAPOR SUPERAQUECIDO COM ATIVIDADE DE ÁGUA MENOR QUE 1,0

DANIEL MARIO TAPIA TAPIA

Aprovada em: 22. 08. 1997

Comissão julgadora:

Prof. Dr. Luiz Gonzaga do Prado Filho

ESALQ/USP

Prof. Dr. Aline Aparecida Pizarine-Kleiner

ESALQ/USP

Prof. Dr. Luiz Eduardo Gutierrez

ESLAQ/USP

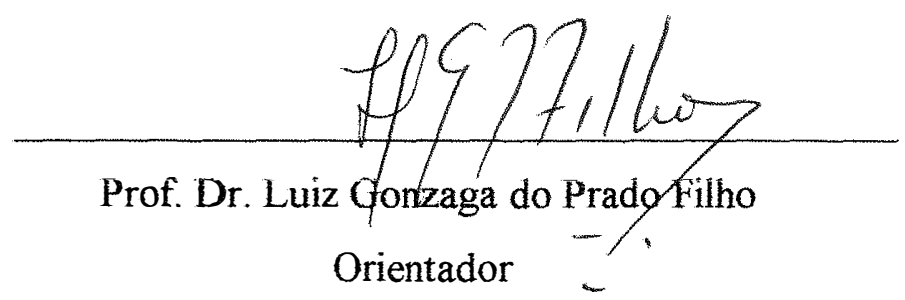


dos mans pais suillermo o I vaia

openaco

A minha espasa Carba, a aos meus

funcos Sivillermo e Camikn, palo sen carinho, amos e apoio constants. deatico. 
Página

LISTA DE TABELAS ............................................................ vii

LISTA DE FIGURAS …......................................................... viii

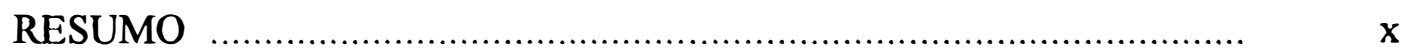

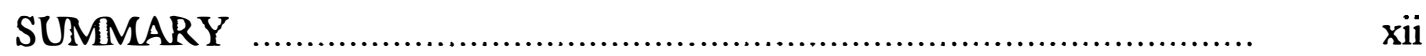

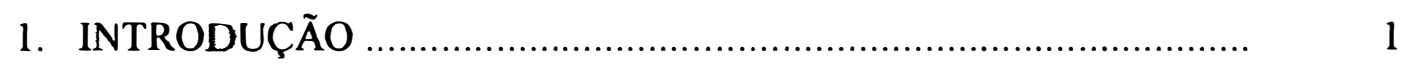

2. REVISÃO DE LITERATURA …............................................. 3

3. MATERIAL E MÉTODOS ....................................................... 23

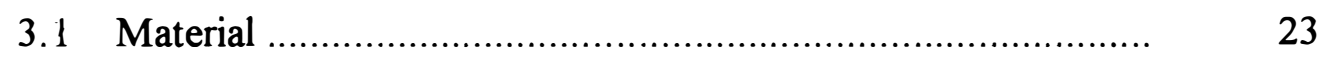

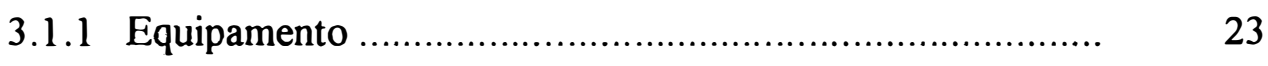

3.1.2 Microrganismo estudado .......................................... 23

3.1.3 Meio de cultura empregado ….................................... 26

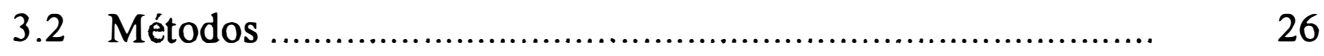

3.2.1 Produção de esporos …….............................................. 26

3.2.2 Preparo das amostras para tratamento ........................... 27

3.2.3 Tratamento e manuseio das amostras ….......................... 28

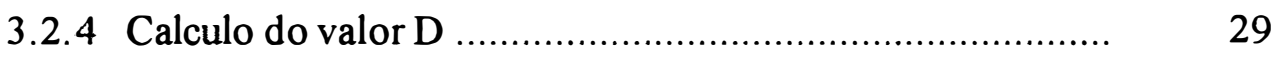

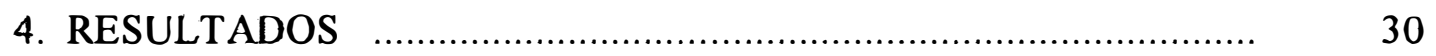

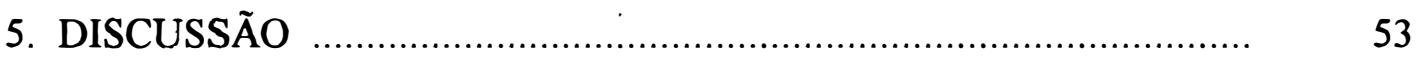

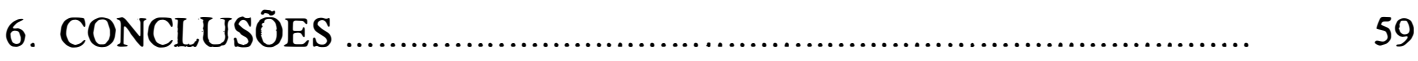

7. REFERÊNCIAS BIBLIOGRÁFICAS …........................................ 61 


\section{LISTA DE TABELAS}

Número

Página

1_ Número de UFC e cálculo do valor D através da formula de Stumbo (1973) $\mathrm{Dt}=\mathrm{t} /(\log . \mathrm{a}-\log . \mathrm{b})$ para tratamento a $100^{\circ} \mathrm{C}$ e Aa média $=0,951 \ldots$

2_ Número de UFC e cálculo do valor D através da formula de Stumbo (1973) $\mathrm{Dt}=\mathrm{t} /(\log \mathrm{a}-\log \mathrm{b})$ para tratamento a $110^{\circ} \mathrm{C}$ e Aa média $=0,672$

3 Número de UFC e cálculo do valor D através da formula de Stumbo (1973) $\mathrm{Dt}=\mathrm{t} /(\log \mathrm{a}-\operatorname{lob} \mathrm{g})$ para tratamento a $120^{\circ} \mathrm{C}$ e Aa média $=0,482$

4- Número de UFC e cálculo do valor D através da formula de Stumbo (1973) $\mathrm{Dt}=\mathrm{t} /(\log \mathrm{a}-\log \mathrm{b})$ para tratamento a $130^{\circ} \mathrm{C}$ e Aa média $=0,355$

5 Número de UFC e cálculo do valor D através da formula de Stumbo (1973) $\mathrm{Dt}=\mathrm{t} /(\log \mathrm{a}-\log \mathrm{b})$ para tratamento a $140^{\circ} \mathrm{C}$ e Aa média $=0,264$

6 Número de UFC e cálculo do valor D através da formula de Stumbo (1973) $\mathrm{Dt}=\mathrm{t} /(\log \mathrm{a}-\log \mathrm{b})$ para tratamento a $150^{\circ} \mathrm{C}$ e Aa média $=0,20$

$7 \quad$ Número de UFC e cálculo do valor D através da formula de Stumbo (1973) $\mathrm{Dt}=\mathrm{t} /(\log \mathrm{a}-\log \mathrm{b})$ para tratamento a $160^{\circ} \mathrm{C}$ e Aa média $=0,153$

8 Valores D máximos calculados pela formula $\mathrm{D}=\mathrm{t} /(\log \mathrm{a}-\log \mathrm{b})$, extrapolação gráfica e pela equação de regressão.

9_ Ocorrência de esporos hiperresistentes detectados com um minimo de tempo 
viii

\section{LISTA DE FIGURAS}

Número

Página

1_ Esquema geral do equipamento montado

2 Câmara de tratamento

3_ Gráfico da inativação de esporos de Bacillus cereus IAL 2599 a $100^{\circ} \mathrm{C}$ e Aa média $=0,951$

4 _ Gráfico da fração mais resistente da população de esporos de Bacillus cereus IAL 2599 a $100^{\circ} \mathrm{C}$ e Aa média $=0,951$

5 Gráfico da inativação de esporos de Bacillus cereus IAL 2599 a $110^{\circ} \mathrm{C}$ e Aa média $=0,672$

6 Gráfico da fração mais resistente da população de esporos de Bacillus cereus IAL 2599 a $110^{\circ} \mathrm{C}$ e Aa média $=0,672$

7 Gráfico da inativação de esporos de Bacillus cereus IAL 2599 a $120^{\circ} \mathrm{C}$ e Aa média $=0,482$

8_ Gráfico da fração mais resistente da população de esporos de Bacillus cereus IAL 2599 e Aa média $=0,482$

9_ Gráfico da inativação de esporos de Bacillus cereus IAL 2599 a $130^{\circ} \mathrm{C}$ e Aa média $=0,355$

10 Gráfico da fração mais resistente da população de esporos de Bacillus cereus IAL 2599 e Aa média $=0,355$

11 Gráfico da inativação de esporos e Bacillus cereus IAL 2599 a $140^{\circ} \mathrm{C}$ e Aa média $=0,264$

12 Gráfico da fração mais resistente da população de esporos de Bacillus cereus IAL 2599 e Aa média $=0,264$

13 Gráfico da inativação de esporos de Bacillus cereus IAL 2599 a $150^{\circ} \mathrm{C}$ e Aa média $=0,20$ 
14. Gráfico da fração mais resistente da população de esporos de Bacillus cereus $1 \mathrm{AL} 2599$ a $150^{\circ} \mathrm{C}$ e Aa média $=0,20$

15_ Gráfico da inativação de esporos de Bacillus cereus IAL 2599 a $160^{\circ} \mathrm{C}$ e Aa média $=0,153$

16_ Gráfico da fração mais resistente da população de esporos de Bacillus cereus $1 \mathrm{AL} 2599$ a $160^{\circ} \mathrm{C}$ e Aa media $=0,153$ 


\title{
DETERMINAÇÃO DA RESISTÊNCIA TÉRMICA DE ESPOROS DE Bacillus cereus IAL 2599 FRENTE A VAPOR SUPERAQUECIDO COM ATIVIDADE DE ÁGUA MENOR QUE 1,0
}

\author{
Autor: DANIEL MARIO TAPIA TAPIA \\ Orientador: Prof. Dr. LUIZ GONZAGA DO PRADO FILHO
}

\section{RESUMO}

No presente trabalho foi estudada a resistência térmica de esporos de Bacillus cereus IAL 2599 frente a vapor superaquecido a $100^{\circ} \mathrm{C} ; 110^{\circ} \mathrm{C} ; 120^{\circ} \mathrm{C} ; 130^{\circ} \mathrm{C}$; $140^{\circ} \mathrm{C} ; 150^{\circ} \mathrm{C}$ e $160^{\circ} \mathrm{C}$ que nas condições de pressão atmosférica média de $715 \mathrm{~mm} \mathrm{Hg}$ corresponde às atividade de água (Aa) de $0.951 ; 0,672 ; 0,482 ; 0,355 ; 0,264 ; 0,20$ e 0,153 respectivamente.

Nas temperaturas experimentadas foram observados fenômenos de ativação e inativação simultâneos ou seqüenciais, com exceção de $140^{\circ} \mathrm{C}$ e $\mathrm{Aa}=0,264$. As frações mais resistentes da população tratada não são quantitativamente iguais nas temperaturas estudadas. A aplicação da fórmula de Stumbo (1973), para o cálculo de um valor D que representa toda a população tratada não se mostrou conveniente para o presente estudo. A determinação de um valor D por meio de uma equação de regressão calculada com pontos escolhidos da fração da mais resistente da população, introduz um fator subjetivo que pode levar a superestimação da resistência real. No caso de uso de portadores de 
Bacillus cereus IAL 2599 como bioindicador em processos por calor seco o número de esporos inoculados pode ser limitado a $\mathrm{Nx} 10 \mathrm{E}+6$ o que garante um fator de segurança satisfatório em processos térmicos de natureza semelhante ao estudado.

Nas temperaturas estudadas, no caso de emprego de esporos de Bacillus cereus como bioindicadores de processos térmicos por calor seco, os tempos recomendados de tratamento de objetos infestados por populações naturais de esporos seriam, respectivamente, $10 \mathrm{~min}$ a $100^{\circ} \mathrm{C} ; 30 \mathrm{~min}$ a $110^{\circ} \mathrm{C} ; 50 \mathrm{~min}$ a $120^{\circ} \mathrm{C} ; 20 \mathrm{~min}$. $130^{\circ} \mathrm{C} ; 20 \mathrm{~min}$ a $140^{\circ} \mathrm{C} ; 10 \mathrm{~min}$ a $150^{\circ} \mathrm{C}$ e 5 min. a $160^{\circ} \mathrm{C}$. 
THERMAL RESISTANCE DETERMINATION OF Bacillus cereus IAL 2599

SPORES FACED TO SUPERHEATED STEAM WITH WATER ACTIVITY

LESS THAN 1,0

AUTHOR: DANIEL MARIO TAPIA TAPIA

ADVISOR: PROF. DR. LUIZ GONZAGA DO PRADO FILHO

SUMMARY

In the present paper was studied the thermal resistance of Bacillus cereus IAL 2599 spores faced to superheated steam at $100^{\circ} \mathrm{C} ; 120^{\circ} \mathrm{C} ; 130^{\circ} \mathrm{C} ; 140^{\circ} \mathrm{C} ; 150^{\circ} \mathrm{C}$ and $160^{\circ} \mathrm{C}$, that in the average atmospheric conditions correspond to the following water activities (Aa) 0,$951 ; 0,672 ; 0,482 ; 0,355 ; 0,264 ; 0,20$ and $\bullet, 153$ respectively.

At the experimental temperatures, simultaneous or sequential activation and inactivation phenomena were observed except at $140^{\circ} \mathrm{C}$ and $\mathrm{Aa}=0,264$. The most resistant fraction of the treated population are not quantitatively the same at the studied temperatures. The utilization of the formula according to Stumbo 1973, to calculate the D value, which represents all the population did not show to be convinient in the present study. The determination of a $D$ value through a regression equation calculated with the chosen points from the most resistant fraction of the population, put in evidence a subjective factor that can lead to a superstimation of the real resistance. In case of using 
carriers of Nacillus creeus IAL 2599 spores as bioindicators in thermal processes by dry heat the number of inoculated spores in the carrier, can be limited to $\mathrm{N} \times 10+6$, which give a satisfactory factor of security in thermal processes with the same nature as the one studied here.

At the studied temperatures, in case of using Bacillus cereus spores in thermal processes as bioindicator by dry heat, the recommended treatments of contamined objects by natural spores populations, would be: $10 \mathrm{~min}$. at $100^{\circ} \mathrm{C} ; 30 \mathrm{~min}$. at $110^{\circ} \mathrm{C} ; 50 \mathrm{~min}$ at $120^{\circ} \mathrm{C} ; 20 \mathrm{~min}$. at $130^{\circ} \mathrm{C} ; 20 \mathrm{~min}$. at $140^{\circ} \mathrm{C} ; 10 \mathrm{~min}$ at $150^{\circ} \mathrm{C}$ and $5 \mathrm{~min}$. at $160^{\circ} \mathrm{C}$ respectively. 


\section{1._Introdução}

Dentro de qualquer sistema um dos fatores que condiciona a atividade microbiológica é a disponibilidade de água, e no caso dos alimentos água disponível, é um fator básico na evolução dos diferentes processos de deterioração. A disponibilidade de água em um alimento ou em um sistema é expressa em termos de atividade de água (Aa) ou umidade relativa (UR).

A atividade de água é definida como a relação entre a pressão de vapor da água de um sistema e a pressão de vapor da água livre á mesma temperatura. Por tanto, os conceitos de atividade de água e umidade relativa se eqüivalem, sendo esta expressa em porcentagens e aquele em frações de umidade.

A influência da atividade de água sobre a resistência térmica dos esporos de microrganismos é um fator de muita importância a ser considerado nos processos que visam a inativação dos mesmos. Sabe-se que a resistência térmica dos esporos de microrganismos aumenta com a diminuição da atividade de água no ambiente até um dado limite. Na maioria dos casos, a resistência máxima é alcançada no intervalo de $\mathrm{Aa}=0,20$ a $\mathrm{Aa}=0,40$.

Nos estudos sobre resistência térmica de esporos em ambientes de atividade de água menor que 1,0 $(\mathrm{Aa}<1,0)$, é importante conhecer o comportamento dos mesmos em embalagens, matérias primas assim como também em alimentos desidratados ou liofilizados e como estes microrganismos e seus esporos poderiam ser inativados ou destruídos sem a utilização métodos de descontaminação por via úmida, nem sempre conveniente.. 
Dentro destas pesquisas diversos métodos podem ser utilizados para controlar a atividade de água ambiental, sendo o mais comum, o uso de soluções com atividade de água definidas na temperatura na qual se deseja fazer o tratamento térmico.

A espécie Bacillus cereus é um microrganismo que ocorre com muita frequência em produtos lácteos (leite "in natura" e, derivados) sendo responsável por toxinfecções alimentares.

Sendo vapor superaquecido um agente de tratamento térmico empregado para descontaminação de alguns tipos de embalagens e, equipamentos, em instalações ligadas à industrialização de alimentos e produtos farmacêuticos, o conhecimento da resistência térmica de microrganismos nas condições estudadas neste trabalho, pode contribuir para o estabelecimento de parâmetros mais definidos de bioindicadores de processos térmicos empregando calor seco usando esporos de Bacillus cereus como organismo teste. Dados relativos a resistência térmica de esporos de Bacillus cereus ao calor seco são muito raros na literatura especializada e, inexistem quanto à cepa IAL 2599, patógeno, isolado de alimentos por pesquisadores do Instituto Adolfo Lutz da Secretaria de Saúde do Estado de São Paulo.

O presente trabalho teve como objetivo determinar a quantitativamente a resistência térmica de esporos de Bacillus cereus IAL 2599 frente vapor superaquecido com atividade de água menor que 1,0 . 


\section{2_Revisão de Literatura}

A resistência térmica de microrganismos à ação do calor seco, ou seja, em condições nas quais a atividade de água é menor que 1,0, tem-se constituído em um campo de pesquisa muito limitado dentro do contexto de esterilização de alimentos. O problema estava afeto à área das indústrias farmacêuticas. Mesmo nestas industrias onde o calor seco é utilizado mais amplamente, não existe ainda uma norma definida de aplicação geral. No artigo publicado por Roemer (1975) este fato está bem caracterizado embora, mais recentemente hajam sido estabelecidos valores mais definidos (Russel et alii, 1992). Embora a aplicação do calor seco seja mais restrita que o calor úmido, o qual é mais efetivo como esterilizante, existe a necessidade de estudos adicionais pois, existem produtos e equipamentos cuja esterilização por calor úmido não é conveniente ou, mesmo possível .

Portanto, no presente estudo procuramos dar ênfase aos trabalhos relativos ao emprego de calor seco na inativação de esporos de bactérias por calor seco de interesse na indústria de alimentos.

Collier \& Townsed (1955), estudaram o comportamento de esporos de P.A. 3675, Bacillus stearothermophilus 1518 e Bacillus polimyxa em um sistema de enlatamento asséptico fabricado pela James Doyle Engeneering Company. Na pesquisa foi evidenciada a variação da resistência térmica de B. polimyxa e B. stearothermophilus 1518 em função da umidade do meio de tratamento, Este trabalho praticamente desperta o interesse de pesquisadores para o estudo do 
comportamento de microrganismos sob tratamento térmico em ambiente de atividade de água menor que 1,0 , ou umidade relativa menor que $100 \%$.

Pflug (1960), com a finalidade de estudar o comportamento de esporos de Bacillus subtilis 5230 em vapor saturado, ar e vapor superaquecido construiu um termorresistômetro. Neste trabalho não foram indicadas as velocidades dos gases na câmara de tratamento, nem as temperaturas que permitam uma avaliação da atividade de água reinante durante os experimentos realizados. $\mathrm{O}$ valor $\mathrm{D}$ exato não pode ser calculado, sendo a resistência expressa em $\mathrm{LD}_{50}$ a $350^{\circ} \mathrm{F}\left(176,6^{\circ} \mathrm{C}\right)$.

Murrel \& Scott (1966), trabalharam com Bacillus megaterium, Bacillus stearothermophilus ATCC 7953, Bacillus coagulans, Clostridium botulinum E ATCC 9564, Clostridium botulinum B ATCC 7949 e Clostridium bifermentants estabelecendo que a resistência máxima dos esporos tratados era no intervalo de atividade de água 0,2 a 0,4 , sendo que para os esporos de Bacillus megaterium a resistência máxima no intervalo citado era 10.000 vezes maior que a resistência no intervalo de $\mathrm{Aa}=1,0$. Neste experimento foram utilizados esporos liofilisados condicionados na presença de soluções controladoras de atividade de água.

Pfeil et alii (1967) estudaram os efeitos dos gases (ar, $\mathrm{He}, \mathrm{N}, \mathrm{O}$ e $\left.\mathrm{CO}_{2}\right)$ sobre a inativação térmica por calor seco em esporos de Bacillus subtilis 5230 e Clostridium sporogenes PA 3679-45. Os esporos inoculados em cadinhos de estanho $(11 \times 8 \mathrm{~mm}$.) e após secagem a vácuo a $25{ }^{\circ} \mathrm{C}$ por 25 horas, dez unidades eram fixadas em latas especiais (latas TDT $64 \times 8 \mathrm{~mm}$.) em atmosfera dos gases em estudo. $\mathrm{O}$ tratamento foi executado em autoclave a $121,1^{\circ} \mathrm{C}, 143,3^{\circ} \mathrm{C}$, $148,9^{\circ} \mathrm{C}, 154,5^{\circ} \mathrm{C}, 160^{\circ} \mathrm{C}$. Os esporos de B. subtilis 5230 apresentaram resistência maior a temperaturas abaixo de $143^{\circ} \mathrm{C}$ em todos os gases, entre 143,3 e $148,9^{\circ} \mathrm{C}$ as resistências se eqüivalem passando C. sporogenes PA $3679-45$ a mais resistente acima de $148,9^{\circ} \mathrm{C}$ em função do seu valor " $Z$ " maior. Os valores $D$ são maiores em He e $\mathrm{N}$ para ambos microrganismos, não 
influenciando o peso molecular na distribuição energética, nem mostrando oxigênio, especial efeito inativador como anteriormente era suposto.

Bruch \& Smith (1968) utilizando esporos de Bacillus subtilis var. niger inoculados sobre pedaços de Kapton e Teflon, verificaram que ocorriam divergências no valor $Z$ e D. Os autores calcularam $\mathrm{Z}$ igual a $29,1^{\circ} \mathrm{C}$ para o Kapton, e $\mathrm{Z}$ igual a $139^{\circ} \mathrm{C}$ para esporos sobre Teflon. Essa divergência estaria relacionada com a atividade de água reinante no ambiente em que o esporo se encontrava. No caso do filme de Kapton, este é permeável ao vapor d'água formado durante o processo, enquanto que no caso do Teflon por ser impermeável permitia o aquecimento dos esporos em um ambiente de atividade de água intermediária, dando assim alta resistência.

Hofmann et alii (1968) estudaram a resistência térmica dos esporos de Bacillus subtilis var. niger condicionados a $25^{\circ} \mathrm{C}$ por 48 horas em ambiente com $11 \%, 33 \%$ e $85 \%$ de umidade relativa antes do tratamento. O equipamento utilizado foi uma placa de aquecimento, com os esporos pipetados em lâminas de aço de $13 \times 13 \times 0,3 \mathrm{~mm}$. A disposição do equipamento utilizado caracterizou um sistema aberto, o que nas temperaturas de tratamento $\left(125^{\circ} \mathrm{C}, 135^{\circ} \mathrm{C}\right.$ e $164^{\circ} \mathrm{C}$ ) correspondia uma atividade água igual a 0.03 . Nas condições do experimento não houve influência da atividade de água sobre a resistência durante o tratamento, porém a atividade de água do condicionamento teve influência marcante, apresentando os esporos mais úmidos, um a maior resistência

Angelotti et alii (1968) estudaram os problemas de descontaminação de veículos espaciais. As amostras foram tratadas em tubos TDT imersos em banho de silicone com temperaturas de $105^{\circ} \mathrm{C}$ a $160^{\circ} \mathrm{C}$. Nos esporos equilibrados a diversas atividades de água, a maior resistência térmica detectada a $135^{\circ} \mathrm{C}$ foi a dos esporos equilibrados entre $\mathrm{Aa}=0,2 \mathrm{e} A \mathrm{a}=0,4$. Os esporos estudados eram de Bacillus subtilis var. niger. 
Fox \& Pflug (1968) para estudar os efeitos dos gases sobre a resistência térmica de esporos de Bacillus subtilis 5230 construíram um equipamento constituído de um bloco de alumínio provido de barras do mesmo metal deslizando como gavetas para o interior do bloco, e suportando cadinhos de estanho cujas dimensões eram $11 \mathrm{~mm}$ de diâmetro x $8 \mathrm{~mm}$ de altura, que recebiam a suspensão de esporos liofilizados. Ar ou nitrogênio escoando sobre as amostras tinham suas velocidades variadas em função da vazão dada $\mathrm{em} \mathrm{ft}^{3} / \mathrm{min}$, não havendo controle da umidade dos gases. Os autores encontraram dificuldades em recuperar os esporos após o tratamento, devido á fixação dos mesmos ao fundo dos cadinhos, determinando também uma diminuição da resistência com aumento da vazão dos gases. Uma diferença de resistência devido à propriedades dos gases não foi claramente estabelecida. Foi detectado que a $140^{\circ} \mathrm{C}$ cerca de $1 \%$ da população, apresentou resistência maior que a restante, sendo esta fração a considerada para os cálculos do valor $\mathrm{D}$.

King et alii (1969) utilizando o método descrito pela National Canners Association estudaram a resistência térmica de Byssochlamys fülva. A resistência térmica era determinada em suco concentrado de uva e em suco de uva reconstituído. Os valores $Z$ encontrados foram $6.7^{\circ} \mathrm{C}$ para o experimento com suco concentrado e $6.1^{\circ} \mathrm{C}$ para o experimento com suco reconstituído. Para as diferentes cepas obtidas de coleção de culturas, os valores D encontrados a $87,8^{\circ} \mathrm{C}$ variavam de 4,8 a 8,5 minutos enquanto que para as cepas originais do suco, o valor $\mathrm{D}$ encontrado foi de 11,3 minutos.

Fox \& Eder (1969) estudaram a resistência térmica de esporos de Bacillus subtilis submetidos a tratamento por calor úmido e seco, utilizando latas apropriadas (TDT cans) e autoclave. A população estudada comportou-se de maneira variável, apresentando "ombro " sob calor úmido e duas frações de resistência distintas sob calor seco. Este comportamento foi 
atribuído a fenômenos simultâneos de ativação e inativação e à diferença de eficiência do choque térmico úmido, e do choque térmico seco, na ativação dos esporos.

Drumond \& Pflug (1970) trabalhando com esporos de Bacillus subtilis conservados em etanol $95 \%$ por vários meses, sendo depois congelados a $-10^{\circ} \mathrm{C}$ descongelandoos no momento do uso, verificaram uma variação de resistência em amostras do mesmo lote, quando tratados em dias diferentes. As amostras eram incubadas em chapas de aço inox de $25,4 \mathrm{x}$ $50,8 \mathrm{~mm}$ e posteriormente equilibrados a $2 \%$ e $89 \%$ de umidade relativa por 12 horas. A atividade de água era de 0,011 e 0,0034 . Os autores não consideraram o número inicial de esporos.

Alderton \& Snell (1970) estudaram a resistência térmica de esporos de Bacillus stearothermophilus NCA 1518 em ambientes com atividades de água intermediária $(\mathrm{Aa}<1.0)$, utilizando tubos apropriados (TDT Tubes) e aquecimento em banho de óleo. As atividades de água nas temperaturas pesquisadas eram obtidas por deposição de água nas paredes dos tubos, em quantidades tais que, após a evacuação e selamento dos mesmos, as atividades de água eram obtidas. Os experimentos foram conduzidos ás temperaturas de $125^{\circ} \mathrm{C}, 130^{\circ} \mathrm{C}, 135^{\circ} \mathrm{C}, 140^{\circ} \mathrm{C}$, $145^{\circ} \mathrm{C}, 150^{\circ} \mathrm{C}, 154^{\circ} \mathrm{C}$ e $160^{\circ} \mathrm{C}$, sendo a atividade de água 0,28 . Foi determinado pelos autores que em $A a=1,0$ e $A a=0,0$, o valor " $Z$ " do microrganismo é apenas função da temperatura, mas quando a atividade de água passa a ser função de " $Z$ " é muito mais complexa. A justificativa para trabalhar com $\mathrm{Aa}=0,28$, era de que em um experimentos preliminares os esporos apresentaram maior resistência a essa atividade de água.

Toda (1970) utilizando esporos de Bacillus subtilis para desenvolver sua teoria sobre a não linearidade da resistência térmica de esporos, propôs uma ativação em estágios múltiplos sucessivos, com a possibilidade dos esporos passarem de um estágio de ativação para o seguinte ou diretamente para o estado não viável. Concluiu que a não homogeneidade das 
populações no tocante á habilidade de germinação é uma das causas de curvas não logarítmicas de sobrevivência.

Bond et alii (1971) estudando a resistência térmica de esporos de Bacillus sp. ATCC 27380, coletados de amostras do solo de cabo Kennedy, verificaram que estes esporos eram extremamente resistentes ao calor seco, sendo o valor D $125=139$ horas. $\mathrm{O}$ solo contendo esporos era suspenso em soluções de álcool etílico a $95 \%$ e em seguida, porções de $0.1 \mathrm{ml}$ da suspensão era aplicada em tiras de aço $(0,5$ pol. x 0,5 pol. $)$ para posterior tratamento.

Branenn \& Garst (1972) usaram esporos de Bacillus subtilis var. niger para estudar a possibilidade de equacionar um modelo cinético incorporando a umidade relativa como um dos parâmetros. Tal modelo poderia ser útil na estimativa da esterilização de espaço naves em ciclos de $115^{\circ} \mathrm{C}$ e $125^{\circ} \mathrm{C}$, partindo da dados obtidos a $105^{\circ} \mathrm{C}$. Foi utilizada uma estufa a $105^{\circ} \mathrm{C}$ com ar circulante totalmente renovado a cada $1.0 \mathrm{~min}$. com atividade de água variando entre 0,000033 e 0,00167. A precisão da atividade de água foi obtida pela saturação do ar, com posterior condensação ao ponto de orvalho em temperaturas tais que após o aquecimento a $105^{\circ} \mathrm{C}$, os valores desejados eram obtidos. 0 esporos estocados em etanol $95 \%$ foram inoculados em discos de alumínio de $31,7 \mathrm{~mm}$ de diâmetro x $0,047 \mathrm{~mm}$ de espessura e recobertos por outro disco, sendo as menores resistências detectadas no intervalo de aw $=0,0002$ a 0,0008 .

Prado Filho \& Kiefer (1974) publicaram um esquema de construção de um equipamento para o tratamento térmico de esporos de bactérias em corrente de gases a pressão atmosférica, cuja atividade de água podia ser parcialmente controlada em temperaturas entre $100^{\circ} \mathrm{C}$ e $200^{\circ} \mathrm{C}$

Reynolds et alii (1974) publicaram os resultados de pesquisas de inativação por calor seco, de esporos isolados do solo de dependências para montagem de veículos espaciais, no Centro Espacial de Cabo Kennedy. O equipamento utilizado foi uma estufa com volume de 
$0,016 \mathrm{~m}^{3}$ com recirculação do ar que a $25^{\circ} \mathrm{C}$ tinha uma $\mathrm{UR}=30 \%$. As temperaturas empregadas foram $105^{\circ} \mathrm{C} ; 110^{\circ} \mathrm{C} ; 115^{\circ} \mathrm{C} ; 120^{\circ} \mathrm{C}$ e $125^{\circ} \mathrm{C}$ com e sem tratamento de esporos por radiação, tratamento este feito com vistas á detecção de ação sinérgica. A $125^{\circ} \mathrm{C}$ foi detectada uma fração com um valor $\mathrm{D}=29$ horas, sendo esse valor maior que aquele considerado para Bacillus subtilis var. niger, tomado como padrão de resistência ao calor seco. Em todas as temperaturas foi detectada uma fração mais resistente a qual representava cerca de $1 \%$ do total.

Emborg (1974) estudou a ação conjunta da radiação e calor seco na inativação de microrganismos. Esporos de Bacillus subtilis;Bacillus globigü ATCC 9372 e Bacillus sphaericus eram inoculados em folhas de polietileno, equilibrados por cerca de 12 horas e UR= $30 \%$, então tratados simultaneamente por radiação $(25$ a $70 \mathrm{Krad} / \mathrm{h})$ e calor seco a $100^{\circ} \mathrm{C}$. No sistema de tratamento, não havia movimentação de gás, nem controle da atividade de água. Nas condições testadas Bacillus sphaericus mostrou-se mais resistente.

Scholefield \& Abdelgadir (1974) separaram esporos lisos e rugosos de Bacillus stearothermophilus NCIB 8923 através de centrifugação. As frações separadas exibiram grande resistência térmica e uma marcante ativação térmica na presença de altos níveis de cálcio, ferro e ácido dipicolínico. Usando as diferenças constatadas entre as curvas de sobreviventes das duas frações e a natureza não linear das mesmas. Os autores concluíram a existência de frações altamente resistentes de esporos nas duas frações.

No ano seguinte Prado Filho (1975 a) publicou um estudo sobre os parâmetros termodinâmicos envolvidos na inativação térmica de esporos de Bacillus subtilis var niger ATCC 9372 por calor seco em corrente de ar e $\mathrm{CO}_{2}$. O autor verificou que a energia livre de ativação $\left(\Delta \mathrm{F}^{*}\right)$ para a destruição térmica de esporos de bactérias em atmosferas gasosas de baixa atividade de água, é praticamente independente da 
temperatura, da umidade dos esporos e da composição da atmosfera de tratamento. Os valores baixos de entropia de ativação $\left(\Delta S^{*}\right)$ indicavam que a inativação se dava pelo rompimento de poucas ligações importantes para a atividade biológica, mas sem influência marcante na formação das moléculas envolvidas

Molin \& Östlund (1975) montaram um equipamento experimental para estudar o emprego da radiação infravermelha na esterilização por calor seco. $\mathrm{O}$ microrganismo estudado foi Bacillus subtilis ATCC. 6333, inoculados em lâmínulas de microscopia os quais eram posteriormente equilibrados de 3 a 10 dias a $21{ }^{\circ} \mathrm{C}$ e $79 \%$ de umidade relativa. A atividade de água do sistema variou de 0,001 a 0,005 . Nos valores baixos de atividade de água reinante, a resistência era função da temperatura, porém, em todas as temperaturas foi detectado uma fração da população com resistência maior. Os autores atribuíram esta diferença na resistência à diferença fisiológica dos esporos no momento da coleta.

Bond \& Favero (1975) estudando a resistência térmica de uma espécie de Bacillus (Bacillus sp. ATCC 27380) isolado do solo do Centro Espacial de Cabo Kennedy. Os esporos aquecidos por calor seco a temperaturas superiores a $125^{\circ} \mathrm{C}$ apresentavam "ombro" característico de ativação e destruição térmica simultâneos. O número de esporos viáveis antes do tratamento térmico, foi calculado em cerca de apenas $2,5 \%$ da população realmente presente na amostra. A resistência a $130^{\circ} \mathrm{C}(\mathrm{Aa}<0,01)$ foi caracterizada por um valor $\mathrm{D}$ extremamente alto ( $\mathrm{D}=54 \mathrm{~h}$ ). Nas condições experimentais a resistência foi função apenas da temperatura, tendo sido possível o calculo de um $Z=15^{\circ} \mathrm{C}$.

Prado Filho (1975 b) publicou resultados de pesquisas sobre a inativação térmica de esporos de Bacillus subrilis var. niger ATCC 9372 em corrente de ar e de $\mathrm{CO}_{2}$. O equipamento empregado, trabalhava em sistema aberto com aquecimento e resfriamento instantâneo da 
amostra. Os esporos inoculados em lâminas de alumínio $(55 \times 10 \times 0,04 \mathrm{~mm})$ foram equilibrados antes do tratamento em atmosfera com atividade de água 1,$0 ; 0.6 ; 0,3$ e 0,0 . Nas temperaturas testadas $\left(120^{\circ} \mathrm{C}, 130^{\circ} \mathrm{C}, 140^{\circ} \mathrm{C}\right.$ e $\left.150^{\circ} \mathrm{C}\right)$ a atividade de água do ambiente de tratamento foi sempre menor que 0,016. Embora havendo resistência diferente em ar e $\mathrm{CO}_{2}$, em cada gás ela foi função apenas da temperatura e do teor de umidade dos esporos, sendo que o teor de umidade dos esporos foi de $37,2 \%, 13,8 \%$ e $5,0 \%$.

Von Schelhorn \& Heiss (1975) estudaram a influência da umidade relativa sobre a resistência térmica de esporos de fungos. Trabalharam com esporos de Aspergillus niger, Humicola fuscoatra e Byssochlamys fulva, sendo que foi usado $\mathrm{H}_{2} \mathrm{SO}_{4}$ e $\mathrm{P}_{2} \mathrm{O}_{5}$ para manter as diferentes atividades de água no ambiente em que os esporos se encontravam. $\mathrm{O}$ método utilizado para determinar o valor $\mathrm{D}$, constituía-se de um tubo menor contendo os esporos, esta tubo por sua vez era colocado dentro de um tubo maior, no qual havia a substância que daria a atividade de água reinante no meio ambiente. $\mathrm{O}$ tubo maior era selado. Após varias semanas o equilíbrio era atingido, e o conjunto era submetido ao tratamento térmico em banho aquecido nas temperaturas de tratamento desejadas. $\mathrm{O}$ valor $\mathrm{D}$ encontrado para $B$. fulva foi de 25 minutos a $0 \%$ de umidade relativa e temperatura de $120^{\circ} \mathrm{C}$.

Puleo et alii (1975) trabalhando com esporos coletados em ambiente de montagem de naves espaciais, testaram a resistência térmica dos mesmos a $113^{\circ} \mathrm{C}$ e $125^{\circ} \mathrm{C}$, em estufa de ar forçado, sem controle de atividade de água ambiental. Constataram a existência de uma fração da população com $D_{113}=14 \mathrm{~h}$ e $D_{125}=6,2 \mathrm{~h}$.

Alderton et alii (1976), estudaram a resistência térmica de esporos de Clostridium botulinum 62 A e 213 B em vários meios de aquecimento, incluindo alguns alimentos de baixa acidez. Os autores constataram que a resistência térmica dos esporos pode ser aumentada ou diminuída mudando-se os meios de germinação dos esporos, isto é, da forma 
resistente calcificada (germinação na presença de $\left.\mathrm{Ca}(\mathrm{Ac})_{2}\right)$ para a forma sensivel hidrogenada (germinação na presença de $\mathrm{HCl}$ ). Quando esta resistência é medida em ervilhas e aspargos ambos os tipos de esporos vindos da cultura pura apresentaram uma fração potencialmente mais resistente. As formas de esporos resistentes de ambos tipos (62A e 213B), quando presentes em alimentos de baixa acidez podem ser sensibilizados ao aquecimento em $\mathrm{pH}$ normal dos alimentos.

Molin \& Östlund (1976) estudaram a resistência térmica de esporos de Bacillus subtilis var. niger ATCC 937 ao calor seco de radiação infravermelha (Molin \& Östlund, 1975), dando especial enfoque ao número de esporos presentes nas amostras tratadas. Determinaram que as amostras com concentrações intermediárias de esporos mostravam um valor $\mathrm{D}$ mais elevado que concentrações maiores e menores, o valor $\mathbf{Z}$ da população não, era influenciado. Os autores atribuíram essa variação a diferenças de emissão e absorção de calor nas diferentes concentrações de esporos, a diferentes disponibilidades de água no microambiente das amostras devido ás diferentes proporções de esporos em contato com o vidro da lâminula portadora. A presença de ombros levou os autores a não considerar o número inicial de esporos nos cálculos do valor D.

Han (1977) estudou a resistência térmica de Bacillus subtilis var. niger ATCC 9372, Bacillus stearothermophilus 1518, Clostridium sporogenes ATCC 19404 ao calor seco $\left(120^{\circ} \mathrm{C}\right.$ com atividade de água $\left.<0,012\right)$ e ao vapor superaquecido $\left(120^{\circ} \mathrm{C}, \mathrm{Aa}=0,51\right)$, com e sem tratamento prévio com ácido paracético ou água oxigenada. Os esporos foram previamente por 48 horas. em ambiente de atividade de água 1,$0 ; 0,76 ; 0,33$ e 0,0 . O equipamento utilizado foi descrito por Prado Filho \& Kiefer (1974) com entrada adicional de vapor fiuente. Em ar com atividade de água baixa $\left(120^{\circ} \mathrm{C}, \mathrm{Aa}<0,012\right)$ esporos de Bacillus subtilis ATCC 9372 apresentaram maior resistência que esporos de B. stearothermophilus 1518. Em vapor superaquecido $\left(120^{\circ} \mathrm{C}, \mathrm{Aa}=0,51\right)$ a situação inverteu-se, porém a diferença foi muito menor. Em 
ambas as condições Clostridium sporogenes apresentou menor resistência, cerca de dez vezes menor que a resistência de B. subtilis var. niger ATCC 9372.

Fisher \& Pflug (1977) trabalhando com esporos de Bacillus subtilis estudaram o efeito sinergético do tratamento úmido e seco conjugados com radiação. As dosagens de radiação foram 5,10 e $20 \mathrm{Krad} / \mathrm{h}$ e as temperaturas em experimentos prévios variavam entre $76^{\circ} \mathrm{C}$ e $125^{\circ} \mathrm{C}$ com atividade de água variando de 0,25 a 0,82 nos tratamentos por calor seco. Os esporos eram inoculados em plaquetas de aço de $127 \times 127 \mathrm{~mm}$ e equilibrados em $\mathrm{Aa}=0,5$ por $24 \mathrm{hrs}$. Esporos irradiados a $110^{\circ} \mathrm{C}$ apresentaram maior valor $\mathrm{D}$ na região de atividade de água 0,3 a 0,4 ; o mesmo acontecendo com esporos que apenas receberam tratamento térmico a $90^{\circ} \mathrm{C}, 105^{\circ} \mathrm{C}, 110^{\circ} \mathrm{C}$ e $125^{\circ} \mathrm{C}$. Os autores estabeleceram um coeficiente de sinergismo SI。 o qual demonstrou que maiores efeitos sinérgicos são obtidos com o binômio calor seco-radiação $(S I=0,25)$ do que com o binômio calor úmido - radiação $(\mathrm{SI}=1,5)$

Peeler et alii (1977) estudaram a resistência térmica de esporos de Bacillus subtilis var. niger em cadinhos de aço inoxidável, os quais foram fechados em latas $57,2 \times 73 \mathrm{~mm}$ 120 cadinhos por lata, em sistema fechado, visando a descontaminação de espaçonaves. Os esporos foram inoculados que recebiam $\mathrm{P}_{2} \mathrm{O}_{5}$ ou água em quantidade necessária para obter-se varias atividades de água no ambiente, nas temperaturas desejadas. Em experimentos prelininares a $113^{\circ} \mathrm{C}$ e $125^{\circ} \mathrm{C}$ a $A a$ variou de 0,0 a 1,0 e nos experimentos definitivos a $85^{\circ} \mathrm{C}, 90^{\circ} \mathrm{C}, 95^{\circ} \mathrm{C}$, $100^{\circ} \mathrm{C}, 105^{\circ} \mathrm{C}$ e $120^{\circ} \mathrm{C} \mathrm{Aa}<0,01$ e $\mathrm{Aa}=1,0 . \mathrm{O}$ aquecimento foi feito em banho de silicone, havendo necessidade de correção do tempo de aquecimento e resfriamento das latas.

Molin (1977 a) fez um estudo comparativo da resistência térmica de esporos do gênero Bacillus ao calor seco, empregando equipamento de radiação infravermelho (Molin \& Östlund, 1975). Os microrganismos estudados foram: Bacillus cereus NCTB 9372, Bacillus coagulans NCTB 9365, Bacillus megaterium NCTB 9376, Bacillus polimyxa NCTB 8158, 
Bacillus pumilus NCTB 10337, Bacillus stearothermophilus ATCC 7953, Bacillus stearothermophilus NCTB 10339 e Bacillus subtilis NCTB 8054 e Bacillus subtilis var. niger ATCC 9372. Os esporos foram condicionados a $20-24^{\circ} \mathrm{C}$ e $\mathrm{Aa}=0,33$ por $3-10$ dias, foram tratados em temperaturas variando de $90{ }^{\circ} \mathrm{C}$ a $180^{\circ} \mathrm{C}$. Neste intervalo de temperatura, esporos de B. Subtilis var. niger ATCC 9372, tiveram um valor D maior que para outros microrganismos. $\mathrm{O}$ autor verificou ainda que os valores $Z$ dependiam da capacidade de retenção de água pelo esporo.

O mesmo autor (Molin, 1977 b) usando o mesmo equipamento e esporos de Bacillus subtilis var. niger e Bacillus stearothermophilus, estudou a variação do valor $Z$ em calor seco, em intervalos grandes de temperaturas. Para Bacillus subtilis var. niger o gráfico do valor $\mathrm{D}$ versus temperatura é linear em intervalos de $37^{\circ} \mathrm{C}$ a $190^{\circ} \mathrm{C}$, contanto que a umidade seja mantida a níveis baixos e o valor $Z=23^{\circ} \mathrm{C}$ é constante. Para Bacillus stearothermophilus o gráfico é função linear entre $150^{\circ} \mathrm{C}$ e $180^{\circ} \mathrm{C}$ com $Z=29^{\circ} \mathrm{C}$, mas desvia-se da linearidade a temperaturas mais baixas, com decréscimo de valor $Z$. Se os esporos fossem previamente secos, $Z$, na faixa linear $\left(150^{\circ} \mathrm{C}-180^{\circ} \mathrm{C}\right)$ baixava para $23^{\circ} \mathrm{C}$.

Rank \& Pflug (1977) estudaram a resistência térmica de esporos de Bacillus subtilis var. niger, inoculados sobre superficie de metal e sobre batata, aquecidos em forno com ar a $175^{\circ} \mathrm{C}$. Os autores verificaram que os esporos de Bacillus subtilis var. niger são mais resistentes ao calor seco quando inoculados sobre superficie de batata, do que sobre superficie de metal. Após inoculo sobre a superficie de batata e do metal, ambos eram equilibrados a $22^{\circ} \mathrm{C}$ com $50 \%$ de umidade relativa por 18 a 24 horas; para depois sofrerem tratamento. $O$ valor $D_{15 \bullet}$ encontrado para Bacillus subtilis var. niger em superficie de metal era de 0,92 minutos, enquanto que para superficie de batata era de 5,6 min. Os autores justificaram que no caso do metal, o ambiente que cerca os esporos está em equilíbrio com a atmosfera reinante no ar do fomo, 
enquanto que no caso da batata, este ambiente que os cerca está com uma umidade mais baixa que a atmosfera reinante no ar, pois a água difunde continuamente da batata para o ar do formo.

Quast et alii (1977) utilizaram um equipamento asséptico marca DOLE para estudar a resistência térmica de esporos de Bacillus stearothermophilus 1518 frente a vapor superaquecido. Nas temperaturas estudadas $\left(152^{\circ} \mathrm{C} ; 155,6^{\circ} \mathrm{C}\right.$ e $\left.159^{\circ} \mathrm{C}\right)$ a atividade de água teria variado entre 0,15 e 0,20 . Com base nos valores $D$ obtidos nas temperaturas estudadas os autores calcularam um valor $Z=17^{\circ} \mathrm{C}$ e por extrapolação concluíram que 6,3 minutos a $170^{\circ} \mathrm{C}$ é sufíciente para causar uma redução de 10 potências na população de B. stearothermophilus, sendo a recomendação segura, com respeito a Clostridium botulinum considerado 10 vezes menos resistente que o microrganismo pesquisado.

Hamulv et alii (1977) realizaram um trabalho sobre resistência térmica de esporos de Bacillus stearothermophilus em vapor de água, solução aquosa de $\mathrm{NaCl}, \mathrm{LiCl}$, glucose, glicerol, ovo integral em pó, concentrado protéico de peixe e farinha de trigo em várias atividades de água. Em vapor de solução de glicerol, a resistência foi máxima a uma baixa atividade de água, porém, não chegando a zero. Em solução de $\mathrm{NaCl}$ e glucose houve uma pequena variação na resistência térmica com a diminuição da atividade de água, ao passo que em soluções de $\mathrm{LiCl}$, a resistência térmica foi mínima em atividade de água ao redor de 0,5 . Quando aquecido o ovo em pó, concentrado protéico de peixe e farinha de trigo, os esporos apresentaram máxima resistência em valores de atividade de água variando entre 0,2 e 0,4.

Puleo et alii (1978) estudaram a resistência térmica de espécies do gênero Bacillus isolados de áreas de montagem de espaçonaves, com vistas à diminuição da duração dos ciclos de descontaminação. O equipamento utilizado foi uma estufa com nitrogênio fluindo a $31 / \mathrm{min}$, com umidade $1,2 \mathrm{mg} \mathrm{H}_{2} \mathrm{O} / \mathrm{l}$ e as temperaturas foram $105^{\circ} \mathrm{C} ; 111,7^{\circ} \mathrm{C} ; 130^{\circ} \mathrm{C}$ e $135^{\circ} \mathrm{C}$. As espécies estudadas foram Bacillus brevis, Bacillus subtilis, Bacillus coagulans, Bacillus 
sphaericus, Bacillus feimus, Bacillus macerans, Bacillus pumilus, Bacillus polimyxa. Os autores concluíram que a maioria das espécies do gênero Bacillus isolados de espaçonave, tem resistência menor ou no máximo igual a $B$. subtilis var. niger.

Estudos sobre resistência térmica de esporos de Clostridium botulinum G 2A foi realizada por Alderton et alii (1980). Esporos liofilizados foram submetidos a temperaturas de $125^{\circ} \mathrm{C}$ a $160^{\circ} \mathrm{C}$,em ambientes com atividade de água variando de 0,0 a 0,9 . Os métodos de trabalho foram os mesmos descritos anteriormente por Alderton \& Snell (1970). Os autores encontraram em $\mathrm{Aa}=1,0$ um valor $\mathrm{D}$ maior que em $\mathrm{Aa}=0,0$ e estabeleceram, que com a diminuição da umidade ambiental, a resistência de microrganismos cresce, apresentando a $130^{\circ} \mathrm{C}$ e $A a=0,4$ um $D=24,2 \mathrm{~min}$.

Beaman \& Gerhardt (1980) estudaram vinte e oito tipos de esporos sensiveis a lizosima entre sete espécies de Bacillus representativos de termófilos, mesófilos e psicrófilos. A resistência das espécies foi alterada pela desmineralização dos esporos originais para esporos protonados e remineralização dos esporos protonados para esporos calcificados e pela adaptação térmica nas temperaturas de esporulação mínima, ótima e máxima.

Chumney \& Adams (1980) estudando esporos de Clostridium perfrigens NTCC 8798 verificaram que os mesmos tornaram-se sensiveis à inibição pelo cloreto de sódio e a mistura de polimixina e neomicina, quando aquecidos a temperaturas de 70 a $100^{\circ} \mathrm{C}$. Os autores explicam que o aumento da sensibilidade provocada por estes agentes da seguinte maneira: o coeficiente de temperatura da indução dos danos celulares conduziram ao aumento da sensibilidade. Verificaram que na ausência desses agentes, os esporos recuperaram a resistência quase ao mesmo tempo. As combinações dos agentes inibidores tiveram menor efeito sobre os esporos, do que cada um empregado individualmente. 
Srinami \& Loncin (1980) desenvolveram um equipamento para determinar o valor $\mathrm{D}$ de microrganismos à elevadas temperaturas. Para comparar os resultados extrapolados com valores $\mathrm{D}$ determinados convencionalmente, foram feitos experimentos pelo método de Stumbo (1965) utilizando esporos de Bacillus subtilis a $100^{\circ} \mathrm{C}$. A esterilização à alta temperatura por tempo curto é utilizada amplamente hoje em dia. A estimativa correta do tempo de esterilização depende do conhecimento dos microrganismos perante o binômio tempo temperatura. Este modemo processo de esterilização foi utilizado primeiramente, com temperatura entre 130 e $150^{\circ} \mathrm{C}$ por poucos segundos.

Srimani et alii (1980) utilizando este tipo de esterilização determinaram os valores D para esporos de Bacillus stearothermophilus e Bacillus subtilis a temperaturas de $115^{\circ} \mathrm{C}$ e $148^{\circ} \mathrm{C}$. Foi observado que os valores $\mathrm{D}$ permanecem aproximadamente constantes em temperaturas acima de $135^{\circ} \mathrm{C}$. O valor $\mathrm{Z}$ foi $6,4^{\circ} \mathrm{C}$ para Bacillus stearothermophilus e $3,7^{\circ} \mathrm{C}$ para Bacillus subtilis.

Odlang et alii (1981) utilizando esporos de Bacillus subtilis 5230 lioflizados em tampão fosfato, estocados nas temperaturas de $2^{\circ} \mathrm{C}$ a $8^{\circ} \mathrm{C}$ por 9 a 27 meses. Determinaram a sua resistência térmica em um termorresistômetro. Estes esporos foram reconstituídos em solução tampão ou solução salina. Os esporos liofilizados mantiveram a resistência térmica e o nível da populaçãodurante todos os períodos testes. Os valores $\mathrm{D}$ obtidos foram 0,44 a $0,54 \mathrm{~min}$. a $121^{\circ} \mathrm{C}$ e os valores $Z$ de 6,1 a $6,6{ }^{\circ} \mathrm{C}$.

Reyes et alii (1981) pesquisaram a resistência térmica de Bacillus sp.ck 4-6; Bacillus cereus; Bacillus stearothermophilus NCA 1518, Bacillus megaterium HTCC 64583, Bacillus subtilis var. niger, utilizando equipamento e manuseio de amostras propostos por Peeler et alii (1977). A atividade de água no meio ambiente durante o tratamento variou de 0,001 a 1,00 e a temperatura variou de $100^{\circ} \mathrm{C}$ a $125^{\circ} \mathrm{C}$. Para Bacillus subtilis var. niger ATCC 9372 
verificou-se um $\mathrm{F}=99,4 \mathrm{~h}$ a $\mathrm{Aa}=0,07$ e para Bacillus $s p$. ck 4-6 um $\mathrm{F}=99,4 \mathrm{~h}$ a Aa variando de 0,01 a 0,07 . Os autores constataram resistências diferentes em esporos de Bacillus subtilis var niger ATCC 9372 equilibrados à mesma atividade de água $(1,0)$ com e sem contato direto com tampão fosfato.

Prado Filho (1982) estudou a resistência térmica de esporos de Bacillus subtilis var. niger ATCC 9372 sendo que as temperaturas empregadas no tratamento foram: 100; 110; $120 ; 130 ; 140 ; 150$ e $160^{\circ} \mathrm{C}$. A metodologia utilizada consistia em inocular lâminas de alumínio $(10 \times 15 \times 0,02 \mathrm{~mm})$ fixadas em suportes. As amostras eram equilibradas antes do tratamento a temperaturas de $30^{\circ} \mathrm{C}$ e umidade relativa de $75 \%$ por 8 semanas. $\mathrm{O}$ meio de aquecimento utilizado foi vapor superaquecido e a atividade de água variou de 0,153 a 0,951 . O autor constatou que a maior resistência térmica ocorria quando a temperatura era de $130^{\circ} \mathrm{C}$ e $\mathrm{Aa}=0,355$ tendo encontrado um valor $D=123,7$ minutos para esporos inoculados diretamente da suspensão aquosa e um valor $\mathrm{D}=149,9 \mathrm{~min}$. para esporos condicionados por 8 semanas a $30^{\circ} \mathrm{C}$ e $\mathrm{Aa}=0,75$. Também concluiu que a resistência térmica não é a mesma para toda a população verificando sempre existir uma fração mais resistente.

Bayliss \& Waites (1982) estudaram a relação do uso simultâneo de tratamentos com radiações ultravioleta e peróxido de hidrogênio como método de esterilização, concluindo a alta intensidade de radiação ultravioleta $(1,8 \times 10 \mathrm{~mW} / \mathrm{m})$ em esporos de Bacillus subtilis na presença de $2,5 \%$ (peso/volume) de peróxido de hidrogênio resultou em um tempo muito rápido de inativação dos esporos.

Oxborrow et alii ( 1983 ) pesquisaram o efeito da temperatura e umidade relativa na esterilização de óxido de etileno. O microrganismo utilizado foi Bacillus subtilis var niger, e o inoculo era feito em tiras de papel e colocadas em estufa, com admissão do gás esterilizante. Os autores variaram a umidade relativa de 10 a $70 \%$, com incremento de $10 \%$, e a temperatura de 30 
a $70^{\circ} \mathrm{C}$, com incremento de $10^{\circ} \mathrm{C}$. Com isto verificaram que para temperatura acima de $50^{\circ} \mathrm{C}$ e umidade relativa variando entre 30 a $50 \%$, havia pouca influência sobre o valor $\mathrm{D}$. Testes utilizando umidade relativa baixa (10 a 30\%) mostraram um valor D alto. Determinaram um valor $\mathrm{D}=15 \mathrm{~min}$. a $30^{\circ} \mathrm{C}$ e $60 \%$ de UR e $\mathrm{D}=1,1 \mathrm{~min}$ a $70^{\circ} \mathrm{C}$ e $60 \%$ de UR.

Contiero (1984) estudou a resistência térmica de conidiosporos de Aspergillus parasiticus 403, produtor de aflatoxina Bl e Gl, em ar superaquecido. O autor utilizou conidiosporos estocados em suspensão aquosa a cerca de $5^{\circ} \mathrm{C}$. Antes de serem submetidos a tratamento térmico os conidiosporos eram secos a vácuo sendo precondicionados por 48 horas em ambiente de $\mathrm{Aa}=0,75$. As temperaturas de tratamento utilizadas variaram de 50 a $120^{\circ} \mathrm{C}$, e os valores $\mathrm{D}$ encontrados foram $24 \mathrm{~min}$ a $100^{\circ} \mathrm{C}$ e $\mathrm{Aa}=0,032 ; 22,5 \mathrm{~min}$ a $105^{\circ} \mathrm{C}$ e $\mathrm{Aa}=0,027$; $11,5 \min$ a $110^{\circ} \mathrm{C}$ e Aa $=0,024$ e $9,0 \min$ a $115^{\circ} \mathrm{C}$ e $\mathrm{Aa}=0,019$.

Leader (1984) estudou a ação esporicida do peróxido de hidrogênio em concentrações variando de 11,8 a $41,3 \%$ nas temperaturas de 20 a $65^{\circ} \mathrm{C}$, usando esporos secos e úmidos de Bacillus subtilis SA 22 (NCA 72-52). Os esporos secos apresentaram duas vezes mais resistência aos efeitos esporicidas do peróxido de hidrogênio que os esporos úmidos.

Malladis \& Scholefield (1985) desenvolveram uma técnica simples e precisa para a determinação da resistência térmica de esporos. Esta técnica consiste na combinação de um tubo capilar modificado com um bloco sólido aquecido. 0 microrganismo utilizado para obtenção de resultados experimentais foi Bacillus stearothermophilus e temperatura utilizada foi $120^{\circ} \mathrm{C}$. Os resultados mostraram precisão e reprodutibilidade nos resultados do novo método.

Kahoury et alii (1987), trabalharam com esporos de Bacillus megaterium . Bacillus subtilis e Bacillus stearothermophilus colhidos de culturas esporuladas em diferentes temperaturas e na presença de etanol, esses esporos apresentaram resistências térmicas diferentes. 
Existe uma correlação direta entre a temperatura de esporulação e a temperatura de morte dos esporos. Os esporos são mais sensíveis quando formados em meio suplementado com etanol.

Malladis \& Scholefield (1987) estudaram a relação entre as características de resistência térmica e a composição dos esporos bacterianos em cinco cepas de Bacillus stearothermophilus. Foi encontrado uma relação existente entre o ácido dipicolínico, o conteúdo de cálcio dos esporos e as características de resistência térmica. A estabilidade do ácido dipicolínico também tem um significado na resistência térmica.

Feherry et alii (1987) trabalharam uma suspensão aquosa de esporos de Bacillus stearothermophilus ATCC 12980 aquecidos em diferentes temperaturas a vários intervalos de tempo em um resistômetro, sobre meio de cultura com antibiótico suplementado com $0,1 \%$ de amido solúvel (AAMS) sem NaCl, e (AAMS-S) com 0,9\% de $\mathrm{NaCl}$, e incubado a $55^{\circ} \mathrm{C}$. Os esporos não injuriados formaram colônias somente sobre AAMS e AAMS-S, enquanto que os esporos injuriados formaram colônias sobre AAMS. Os valores $\mathrm{D}$ dos esporos recuperados sobre AAMS foram 62,$04 ; 18,00 ; 8,00 ; 3,33$ e 10,5 minutos a 112,$8 ; 115 ; 118,3 ; 121,1$ e $123,9{ }^{\circ} \mathrm{C}$ respectivamente. Os valores $\mathrm{D}$ dos esporos recuperados em AAMS-S foram menores. $\mathrm{O}$ valor $Z$ computado para esporos recuperados em AAMS foi de $8,3^{\circ} \mathrm{C}$, e de esporos recuperados em AAMS-S foi de $7,6^{\circ} \mathrm{C}$.

Brown (1988) apresentou a estrutura de um banco de dados sobre a resistência térmica de esporos bacterianos, esporulação, aquecimento, recuperação de esporos e tempo de redução decimal a diferentes temperaturas. Os dados obtidos por este meio, permitem uma rápida manipulação de uma grande quantidade de análises de informações relativas a resistência térmica de esporos bacterianos. 
Lynch \& Potter (1988) compararam os efeitos dos ácidos málico, acético, cítrico, lático e clorídrico sobre a inativação térmica de esporos de Bacillus stearothermophilus e Bacillus coagulans em salsichas tipo "frankfurter" e massa de salsicha. Para Bacillus stearothermophilus a $12.1^{\circ} \mathrm{C}$ em pH 5,2 não houve diferenças nas taxas de morte térmica, mas em pH 4,6 uma grande taxa de inativação foi observada usando ácidos lático, cítrico ou acético, não ocorrendo o mesmo quando usado ácido málico ou clorídrico. Para Bacillus coagulans a $105^{\circ} \mathrm{C}$ ou $110^{\circ} \mathrm{C}$ e pH 4,5 não houve diferenças na ativação de esporos entre os cinco ácidos, mas essas mesmas temperaturas e $\mathrm{pH} 4,2$, houve uma rápida taxa de inativação destes organismos. A inoculação em emulsão de came no estado ácido e a conservação a $4^{\circ} \mathrm{C}$ por 70 horas diminuiu a resistência dos esporos de Bacillus coagulans em pH 4,5 .

Etoa \& Mitchiels (1988) estudaram esporos de Bacillus stearothermophilus CNCH 5781 que foram suspensos em água destilada. Aliquotas foram inoculadas em tubos capilares em diferentes intervalos de tempos à temperatura subletal de $63^{\circ} \mathrm{C}$ ou $100^{\circ} \mathrm{C}$ para inativação térmica de germinação. Após o choque seguiu-se um tratamento térmico a $121,1^{\circ} \mathrm{C}$ e o valor D obtido foi de $3,5 \mathrm{~min}$.

Morton et alii (1990) determinaram a resistência térmica de esporos toxigênicos e não toxigênicos de Clostridium butyricum. As cepas toxigênicas apresentaram um valor D a $212^{\circ} \mathrm{F}\left(100^{\circ} \mathrm{C}\right)$ de $4,7 \mathrm{~min}$, e valor $\mathrm{D}$ a $170^{\circ} \mathrm{F}\left(76,7^{\circ} \mathrm{C}\right)$ de 2,3 a $2,5 \mathrm{~min}$. para as cepas não toxigênicas a umpH 7,0.

Grisotto (1992), apresentou um plano de construção de uma câmara de tratamento térmico de esporos de microrganismos. Seu funcionamento foi testado fazendo-se tratamentos térmicos sobre esporos de Bacillus subtilis var. niger ATCC 9372 com vapor super 
aquecido à temperaturas de $128^{\circ} \mathrm{C} ; 137^{\circ} \mathrm{C} ; 142^{\circ} \mathrm{C}$ e $150^{\circ} \mathrm{C}$ as quais correspondem atividades de água medias de 0,$40 ; 0,30 ; 0,25$ e 0,20 respectivamente, nas condições ambientais dos experimentos. Os resultados obtidos em todas as temperaturas apresentaram fenômenos de ativação e inativação simultâneos ou seqüenciais e a presença de esporos muito mais resistentes que a média da população tratada. $\mathrm{Na}$ temperatura de $128^{\circ} \mathrm{C} \cdot \mathrm{Aa}=0,40$ o valor $\mathrm{D}$ da fração mais resistente da população de esporos tratada foi de 195,31 minutos. Ao contrario das outras temperaturas na temperatura de $137^{\circ} \mathrm{C}(\mathrm{Aa}=0,30)$ não foi evidenciado fenômenos de ativação ou inativação assim como não foi detectada uma fração mais resistente devido a insuficiência do tempo de tratamento. Os parâmetros técnicos do equipamento supracitado foram publicados por Prado Filho \& Grisotto (1994), e os valores D médios obtidos no estudo foram 242 min.; 32,86 min.; 14,60 min. e $9,72 \mathrm{~min}$.; respectivamente; á $128^{\circ} \mathrm{C} ; 137^{\circ} \mathrm{C} ; 142^{\circ} \mathrm{C}$ e $150^{\circ} \mathrm{C}$ (Prado Filho et alii, 1996). 


\section{3_ MATERIAIS E MÉTODOS}

\subsection{Materiais}

\subsubsection{Equipamento para tratamento de esporos}

O equipamento utilizado é constituído de um gerador de vapor de água à pressão ambiente, de uma seção tubular de ajustagem de temperatura do vapor gerado, e por tanto, da atividade de água do mesmo, e de uma câmara de tratamento de esporos.

O gerador de vapor assim como a seção de ajustagem de temperatura são idênticos aos utilizados por Prado Filho (1987 a) para o estudo da resistência térmica de esporos de Bacillus subtilis var. niger ATCC 9372 frente a vapor superaquecido (Figura 1).

A câmara de tratamento utilizada foi a mesma proposta por Grisotto (1992), para o tratamento de esporos de Bacillus subtilis var. niger ATCC 9372 (Figura 2)

\subsubsection{Microrganismo estudado \\ O microrganismo estudado foi Bacillus cereus IAL 2599 da coleção do Instituto} Adolfo Lutz. 


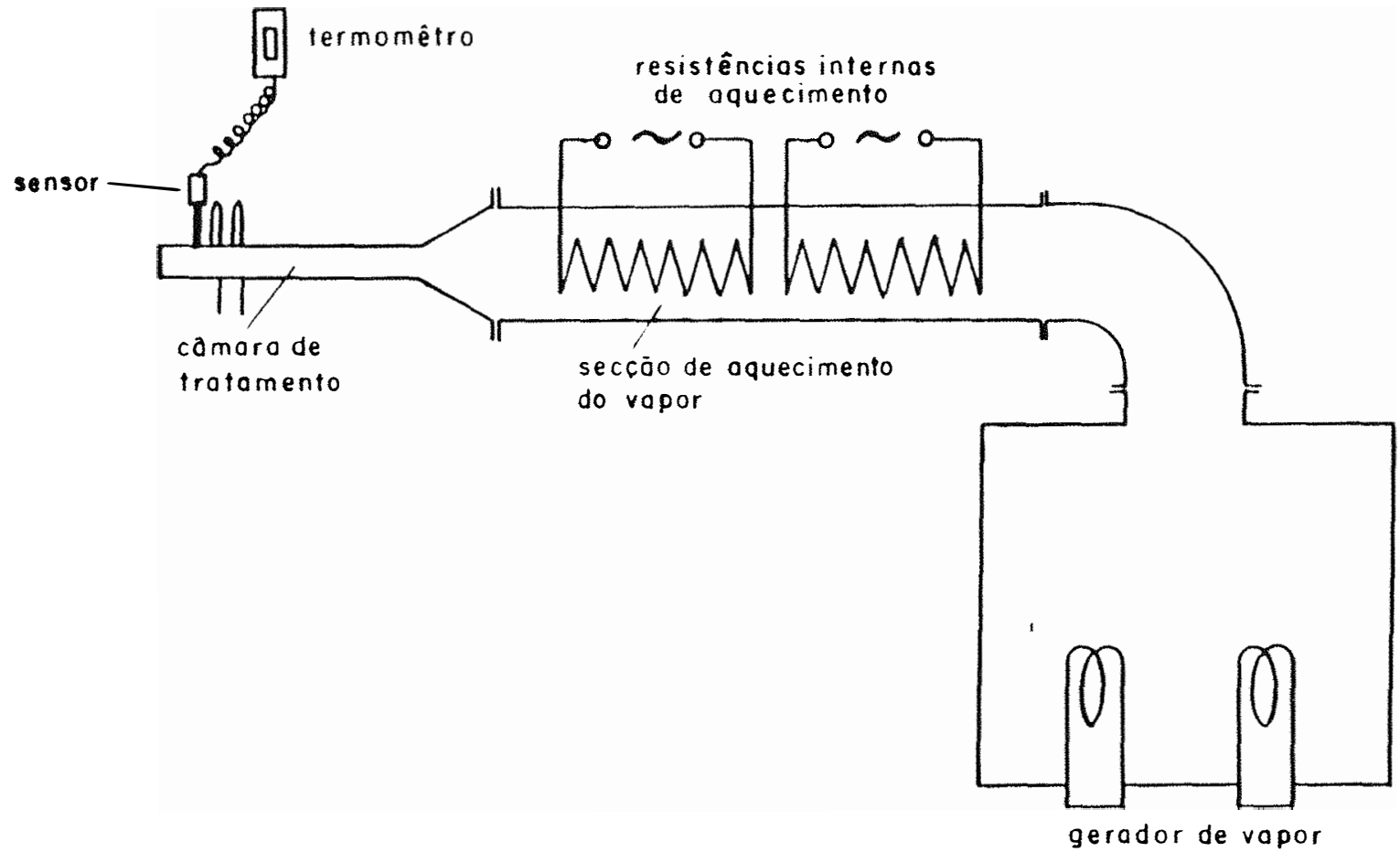

Figura 1-tsquema geral do equipamento montado 


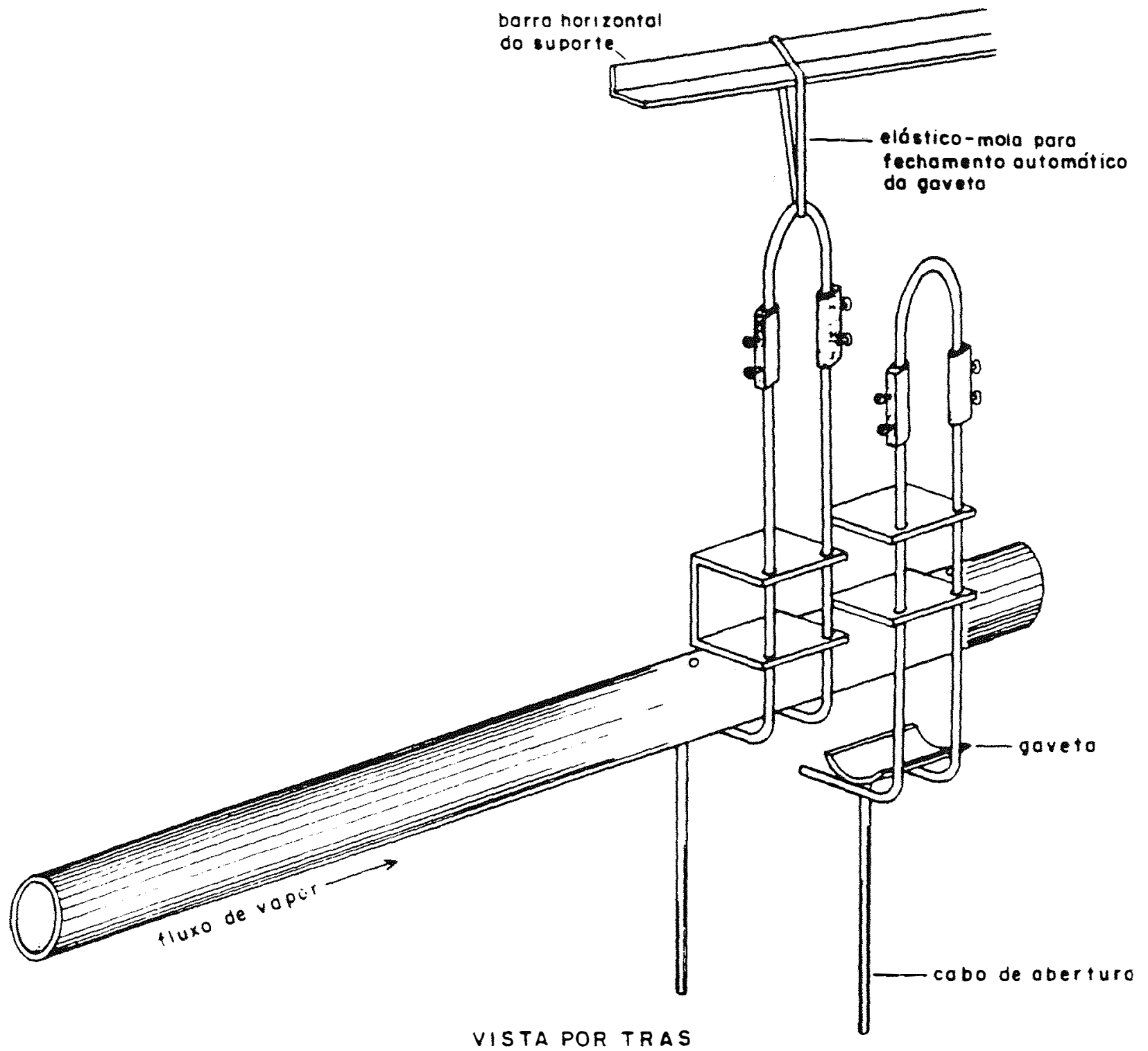

Figura 2-Câmara de tratamento. 


\subsection{3 - Meios de cultura empregados}

Para a ativação dos esporos liofilizados foi utilizado caldo nutriente (GLT) e para a produção de esporos foi utilizado meio especifico de esporulação de Bacillus cereus 0582 (DIFCO).

Para contagem em placa dos esporos viáveis foi utilizado o meio "PLATE COUNT AGAR" PCA (OXOID).

\subsection{Métodos}

\section{2 .1 - Produção de esporos}

Uma cultura estoque de Bacillus cereus IAL 2599 foi revigorada em caldo nutriente GLT por 72 horas a $35^{\circ} \mathrm{C}$. Quando constatada visualmente uma turvação intensa, aliquotas de $2,5 \mathrm{~mL}$ do meio foram transferidas para uma superfície de $100 \mathrm{ml}$ do meio de esporulação 0582 (DIFCO) contidos em frascos ERLERMAYER de $100 \mathrm{ml}$ para obter-se uma superficie maior com pequeno volume de meio. Foram utilizados 3 frascos. Durante a sua incubação a $35^{\circ} \mathrm{C}$ por 72 horas foram feitas observações ao microscópio periodicamente. Foi constatada esporulação praticamente completa transcorridas as 72 horas. Tanto os esporos liberados como as células esporuladas foram colhidas em tubos contendo $10 \mathrm{ml}$ de $\mathrm{H}_{2} \mathrm{O}$ destilada previamente esterilizada raspando-se a superfície com um bastonete de vidro em "L".

Os tubos foram incubados por $24 \mathrm{hrs}$ a $40^{\circ} \mathrm{C}$ para acelerar a liberação dos esporos que ainda estavam contidos nas células.

Após serem incubados, o volume total foi centrifugado a $2500 \mathrm{~g}$. por 15 minutos separando-se a massa de esporos. Esta massa precipitada de esporos foi retomada em tubos 
contendo $20 \mathrm{~mL}$ de água previamente esterilizada. Esta operação foi repetida quatro vezes utilizando-se os sedimentos que sobraram da centrifugação anterior.

Feita a última centrifugação os esporos foram suspensos em tubos de ensaio contendo $10 \mathrm{ml}$ de água destilada e posteriormente estocados a $5^{\circ} \mathrm{C}$ até serem utilizados.

Posteriormente uma das suspensões estocadas sofreu diluições para contagem posterior em câmara de NEUBAUER segundo metodologia de Collins \& Lyne (1970). Esta suspensão estoque contendo $6,87 \mathrm{E}+11$ esporos $/ \mathrm{mL}$ foi utilizada posteriomente para inoculação das lâminas portadoras durante o tratamento.

\subsubsection{Preparação das amostras para tratamento}

As amostras para tratamento seguem o mesmo padrão utilizado por Prado Filho (1987, b) e Grisotto (1992), sendo estas lâminas de alumínio medindo 10 x 15 × 0,02 mm fixadas em suportes com mínina dobradura, e esterilizadas em placas de Petri por 3 a 4 horas. Estas lâminas após esterilização eram inoculadas com uma gota da suspensão de esporos liberados por uma pipeta de Pasteur marca Scientific Products código P 5202 designação ASTME-438-71.

Devido a que este tipo de pipeta padronizada libera gotas uniformes, foi determinado experimentalmente por Prado Filho (1987 b), que para se liberar 1,0 $\mathrm{ml}$ da suspensão, contendo $6,87 \times \mathrm{E}+11$ esporos/mL eram necessárias em média 40 gotas, o que corresponde a uma média de $1,71 \mathrm{E}+10$ esporos inoculados por lâmina, o que eqüivale a $25 \mu$ por lâmina.

Após inoculação, a placa de Petri era transferida para um dissecador, no qual era feito vácuo durante 1.5 minutos, tempo suficiente para que toda a água da gota evaporasse 
deixando contudo os esporos ainda úmidos. Atingido o tempo admitia-se, ar filtrado por algodão lentamente para a quebra do vácuo.

Para cada tratamento duas lâminas foram tratadas e semeadas em quadruplicata.

\subsection{3 - Tratamento e manuseio das amostras}

Uma vez escolhidas as temperaturas e os tempos nos quais o experimento seria efetuado, o equipamento era acionado para se atingir o equilíbrio.

Atingidas as condições desejadas um suporte contendo uma lâmina era introduzida na câmara de tratamento com auxilio de uma pinça flambada, colocando-se na posição horizontal, sendo a gaveta fechada automaticamente pela ação da mola elástica. $\mathrm{O}$ tempo de operação não era maior que quatro segundos. Uma vez fechada a gaveta era acionado um cronômetro elétrico para registro do tempo de tratamento.

Após um intervalo de trinta segundos a mesma operação era repetida com a segunda lâmina. Atingido o tempo estabelecido de tratamento o suporte com a lâmina era transferida rapidamente para um tubo de ensaio contendo $10 \mathrm{ml}$ de uma solução de Tween 80 a $0.01 \%$ em água destilada e $0,5 \mathrm{~g}$ de areia lavada e esterilizada com granulação menor que malha 100 Tyler.

Adotando-se um intervalo máximo de 35 a 40 minutos os esporos eram raspados por meio de um bastão de vidro com ponta de borracha de silicone, sendo então o tubo agitado vigorosamente por 1 minuto, aproximadamente, em agitador elétrico. A seguir eram feitas 6 diluições consecutivas em tubos com $9 \mathrm{~mL}$ de água destilada sendo $1 \mathrm{~mL}$ da diluição plaqueada em quadruplicata em meio PCA OXOID e as placas incubadas a $37^{\circ} \mathrm{C}$ por 48 horas. 


\subsection{3 - Cálculo do valor $\mathbf{D}$}

Para o cálculo do valor D da população de esporos de Bacillus cereus IAL 2599 empregada nos testes foram utilizados dois métodos.

O primeiro deles é o preconizado por Stumbo (1973), o qual emprega a fórmula: $D=t /(\log . \mathbf{a}-\log . \mathbf{b})$

Onde $\mathrm{t}=$ Tempo total de tratamento da amostra a temperatura escolhida.

$a=$ Número de esporos viáveis no inicio do tratamento.

$b=$ Número de esporos viáveis no final do tratamento.

Para a aplicação da fórmula citada, foi tomado como número inicial de esporos o valor $1,72 \mathrm{E}+10$, conforme descrito em 3.2.1, assumindo-se que todos os esporos seriam viáveis.

$\mathrm{O}$ segundo método permite obter o valor $\mathrm{D}$ a partir da equação de regressão calculada através dos dados obtidos, considerando-se apenas a fração mais resistente da população testada e não o número inicial de esporos inoculados. Neste caso o valor $\mathrm{D}$ reflete a resistência da fração mais resistente a cada temperatura e não a resistência média da população global inoculada. 


\section{$4 \quad$ Resultados}

Os resultados obtidos nesta estudo são apresentados em tabelas e gráficos. As tabelas 1 a 7 mostram os o número de UFC e o cálculo do valor D através da fómula de Stumbo (1973). Os gráficos la 14 mostram a evolução geral da destruição térmica dos esporos do microrganismo tratado, bem como, a ocorrência de fenômenos de ativação e intimação e, a evidência de frações mais resistentes da população tratada.

Na Tabela 8 pode ser observada a comparação do valor " $D$ " obtidos pela fórmula de Stumbo (1973), pela equação de regressão e por extrapolação gráfica. 
Tabela 1 _ Número de UFC e cálculo do valor D através da fórmula de Stumbo (973)

$$
\mathrm{D}=\mathrm{t} /(\log \mathrm{a}-\log \mathrm{b}) \text { para tratamento } 100^{\circ} \mathrm{C} \text { e Aa média }=0,951
$$

Tempo de tratamento

U F C

(Média)

$2,7 \mathrm{E}+3 \pm 0.01^{(2)}$

$4,1 \mathrm{E}+4 \pm 0.02$

$6,6 \mathrm{E}+5 \pm 0.03$

$1,3 \mathrm{E}+2 \pm 0.05$

$6,2 \mathrm{E}+2 \pm 0.09$

$1,0 \mathrm{E}+1 \pm 0.01$

$1,6 \mathrm{E} 0 \pm 0.01$
Valor "D"

(minutos)

15

$20^{*}$

$25 *$

$30^{*}$

3,49

*_ Tempos de tratamento considerados no cálculo da equação de regressão

a_ Os dados representam a media de três a quatro determinações, para cada experimento e o desvio padrão 
Tabela 2 _ Número de UFC e cálculo do valor D através da formula de Stumbo (1973)

$$
\mathrm{D}=\mathrm{t} /(\log \mathrm{a}-\log \mathrm{b}), \text { para tratamento a } 110^{\circ} \mathrm{C} \text { e Aa média }=0,672
$$

\begin{tabular}{ccc}
$\begin{array}{c}\text { Tempo de tratamento } \\
\text { (minutos) }\end{array}$ & $\begin{array}{c}\text { U F C } \\
\text { (Média) }\end{array}$ & $\begin{array}{c}\text { Valor "D" } \\
\text { (minutos) }\end{array}$ \\
\hline 5,0 & $8,6 \mathrm{E}+3 \pm 0.10^{(\mathrm{a})}$ & 0,68 \\
10 & $1,4 \mathrm{E}+4 \pm 0.02$ & 1,41 \\
20 & $1,2 \mathrm{E}+4 \pm 0.03$ & 2,93 \\
$30^{*}$ & $1,56 \mathrm{E}+2 \pm 0.10$ & 3,57 \\
$40^{*}$ & $1,65 \mathrm{E}+3 \pm 0.02$ & 4,64 \\
$50^{*}$ & $4,4 \mathrm{E}+3 \pm 0.10$ & 6,06 \\
$60^{*}$ & $5,3 \mathrm{E}+2 \pm 0.05$ & 7,05
\end{tabular}

* _ Tempos de tratamento considerados no cálculo da equação de regressão

a_ Os dados representam a media de três a quatro determinações, para cada experimento e o desvio padrão 
Tabela 3 _ Número de UFC e cálculo do valor D através da formula de Stumbo (1973) $\mathrm{D}=\mathrm{t} /(\log \mathrm{a}-\log \mathrm{b})$, para tratamento a $120^{\circ} \mathrm{C}$ e Aa média $=0,482$

Tempo de tratamento

(minutos)

\section{U F C}

(Média)

\section{Valor "D"}

(minutos)

$\begin{array}{lll}10 * & 7,1 \mathrm{E}+4 \pm 0.01^{(a)} & 1,56 \\ 20 * & 3,4 \mathrm{E}+4 \pm 0.06 & 2,98 \\ 30 * & 3,7 \mathrm{E}+4 \pm 0.09 & 4,50 \\ 40 * & 1,5 \mathrm{E}+4 \pm 0.08 & 5,67 \\ 50 * & 3,1 \mathrm{E}+5 \pm 0.10 & 8,70 \\ 60 * & 3,3 \mathrm{E}+3 \pm 0.04 & 7,77 \\ 70 * & 8,1 \mathrm{E}+2 \pm 0.07 & 9,55 \\ 80 * & 7,6 \mathrm{E}+2 \pm 0.03 & 10,55\end{array}$

*_tempos de tratamento considerados no cálculo da equação de regressão

a_ Os dados representam a media de três a quatro determinações, para cada experimento e o desvio padrão 
Tabela 4 _ Número de UFC e calculo do valor "D” através da formula de Stumbo (1973) $\mathrm{D}=\mathrm{t} /(\log \mathrm{a}-\log \mathrm{b})$ para tratamento a $130^{\circ} \mathrm{C}$ e Aa média $=0,355$

$\begin{array}{ccc}\text { Tempo de tratamento } & \text { U F C } & \text { Valor "D" } \\ \text { (minutos) } & \text { (minutos) } & \text { (minutos) }\end{array}$

$\begin{array}{lll}20 * & 6,0 \mathrm{E}+5 \pm 0.10^{(\mathrm{a})} & 3,66 \\ 40^{*} & 3,0 \mathrm{E}+5 \pm 0.10 & 6,94 \\ 60^{*} & 8,8 \mathrm{E}+4 \pm 0.10 & 9,53 \\ 70^{*} & 8,3 \mathrm{E}+4 \pm 0.10 & 11,08 \\ 100^{*} & 9,8 \mathrm{E}+1 \pm 0.10 & 12,13 \\ 110^{*} & 6,9 \mathrm{E}+1 \pm 0.10 & 13,10\end{array}$

* Tempos de tratamento considerados no cálculo da equação de regressão

a_ Os dados representam a media de três a quatro determinações, para cada experimento e o desvio padrão 
Tabela 5 _ Número de UFC e calculo do valor D através da formula de Stumbo (1973) $\mathrm{D}=\mathrm{t} /(\log \mathrm{a}-\log \mathrm{b})$, para tratamento a $140^{\circ} \mathrm{C}$ e Aa média $=0,264$

\begin{tabular}{ccc}
$\begin{array}{c}\text { Tempo de tratamento } \\
\text { (minutos) }\end{array}$ & $\begin{array}{c}\text { U F C } \\
\text { (Média) }\end{array}$ & $\begin{array}{c}\text { Valor " } \mathrm{D} \text { " } \\
\text { (minutos) }\end{array}$ \\
\hline $20^{*}$ & $3,5 \mathrm{E}+5 \pm 0.08^{\text {(a) }}$ & 4,2 \\
$40^{*}$ & $8,0 \mathrm{E}+4 \pm 0.09$ & 7,5 \\
$60^{*}$ & $3,3 \mathrm{E}+4 \pm 0.05$ & 8,9 \\
$80^{*}$ & $3,2 \mathrm{E}+3 \pm 0.05$ & 10,3 \\
$100^{*}$ & $3,3 \mathrm{E}+2 \pm 0.10$ & 12,9 \\
\hline
\end{tabular}

* Tempos de tratamento considerados no cálculo da equação de regressão

a_ Os dados representam a media de três a quatro determinações, para cada experimento e o desvio padrão 
Tabela 6 _ Número de UFC e cálculo do valor D através da fórmula de Stumbo (1973) $\mathrm{D}=\mathrm{t} /(\log \mathrm{a}-\log \mathrm{b})$, para tratamento a $150^{\circ} \mathrm{C}$ e Aa média $=0,201$

\begin{tabular}{ccc}
$\begin{array}{c}\text { Tempo de tratamento } \\
\text { (minutos) }\end{array}$ & $\begin{array}{c}\text { U F C } \\
\text { (Média) }\end{array}$ & $\begin{array}{c}\text { Valor “ } \mathrm{D} \text { " } \\
\text { (minutos) }\end{array}$ \\
\hline 10 & $1,5 \mathrm{E}+5 \pm 0.09^{\text {(a) }}$ & 1,66 \\
20 & $2,4 \mathrm{E}+3 \pm 0.04$ & 2,55 \\
30 & $3,8 \mathrm{E}+4 \pm 0.08$ & 4,50 \\
40 & $4,2 \mathrm{E}+3 \pm 0.08$ & 5,25 \\
$50^{*}$ & $6,4 \mathrm{E}+4 \pm 0.09$ & 7,70 \\
$60^{*}$ & $3,5 \mathrm{E}+3 \pm 0.10$ & 8,96 \\
$80^{*}$ & $5,8 \mathrm{E}+1 \pm 0.02$ & 9,44 \\
& &
\end{tabular}

* - Tempos de tratamento considerados no cálculo da equação de regressão

a_ Os dados representam a media de três a quatro determinações, para cada experimento e o desvio padrão 
Tabela 7 _ Número de UFC e cálculo do valor D através da fórmula de Stumbo (1973)

$$
\mathrm{D}=\mathrm{t} /(\log \mathrm{a}-\log \mathrm{b}) \text {, para tratamento a } 160^{\circ} \mathrm{C} \text { e Aa média }=0,153 \text {. }
$$

\begin{tabular}{ccc}
$\begin{array}{c}\text { Tempo de tratamento } \\
\text { (minutos) }\end{array}$ & $\begin{array}{c}\text { U F C } \\
\text { (Média) }\end{array}$ & $\begin{array}{c}\text { Valor "D" } \\
\text { (minutos) }\end{array}$ \\
\hline 2,5 & $4,3 \mathrm{E}+3 \pm 0.02^{(\mathrm{a})}$ & 0,33 \\
$5,0^{*}$ & $3,8 \mathrm{E}+4 \pm 0.01$ & 0,75 \\
$7,0^{*}$ & $4,3 \mathrm{E}+2 \pm 0.05$ & 0,81 \\
$10^{*}$ & $1,7 \mathrm{E}+3 \pm 0.06$ & 1,25 \\
$15^{*}$ & $1,2 \mathrm{E}+2 \pm 0.08$ & 1,84 \\
$17^{*}$ & $1,2 \mathrm{E}+1 \pm 0.01$ & 1,85 \\
\hline
\end{tabular}

* Tempos de tratamento considerados no cálculo da equação de regressão

a_ Os dados representam a media de três a quatro determinações; para cada experimento e o desvio padrão 
Tabela 8 _ Valores D máximos, em minutos, calculados pela fórmula de Stumbo (1973) $\mathrm{D}=\mathrm{t} /(\log \mathrm{a}-\log \mathrm{b})$ por extrapolação gráfica e pela equação de regressão linear da fração mais resistente da populaçào

\begin{tabular}{ccccc}
$\begin{array}{c}\text { Temperatura } \\
{ }^{\circ} \mathrm{C}\end{array}$ & Atividade & Valor D máximo & Valor D máximo & Valor D máximo \\
& média (Aa) & pela fórmula & por extrapolação & pela regressão \\
100 & 0,951 & 3,21 & gráfica & linear \\
\hline 110 & 0,672 & 6,46 & 3,9 & 4,72 \\
120 & 0,482 & 9,57 & 27,1 & 28,40 \\
130 & 0,355 & 13,10 & 34,1 & 35.10 \\
140 & 0,264 & 12,97 & 19,2 & 21,35 \\
150 & 0,200 & 9,44 & 26,01 & 27.01 \\
160 & 0,153 & 1,85 & 11,2 & 11,5 \\
\hline
\end{tabular}




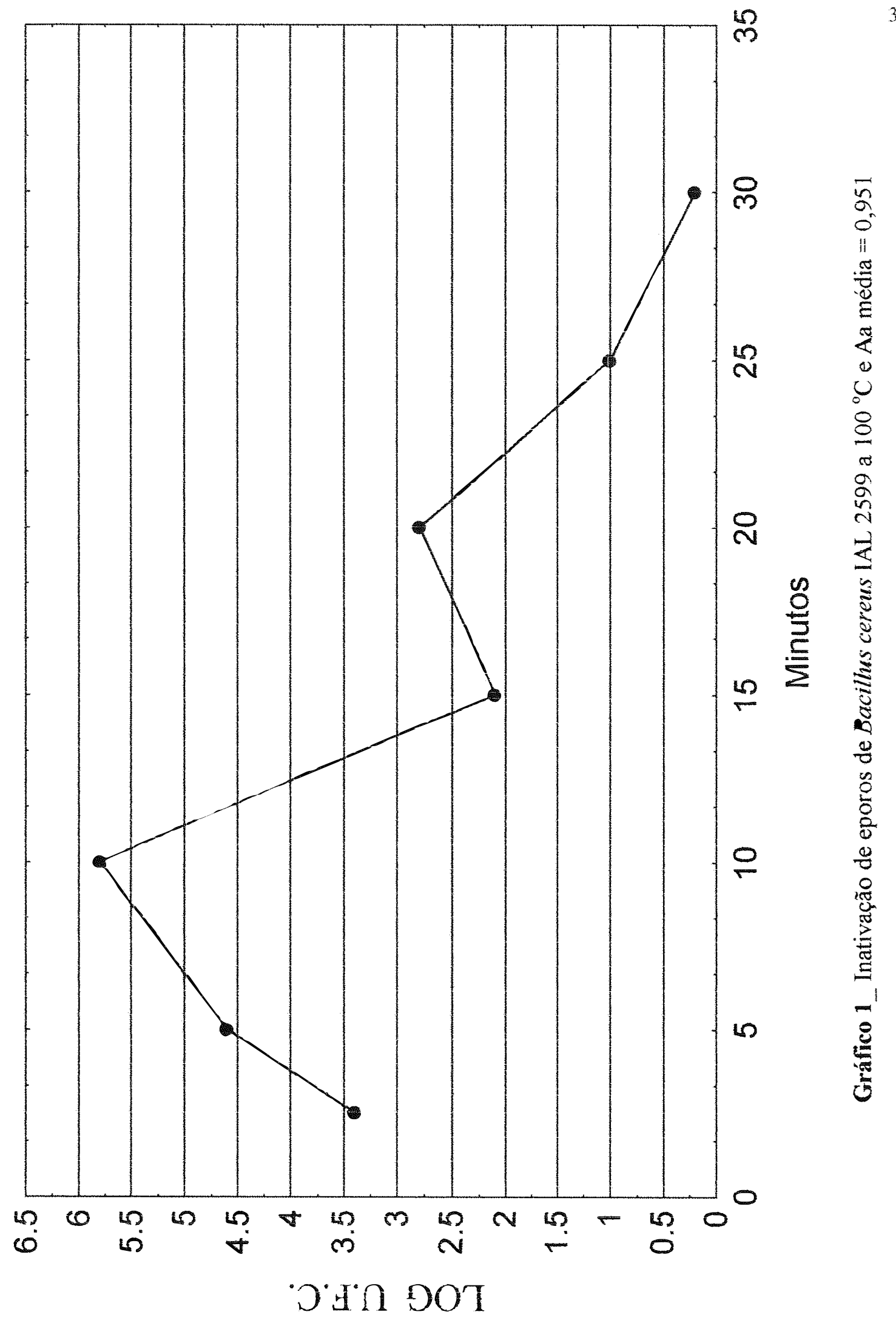




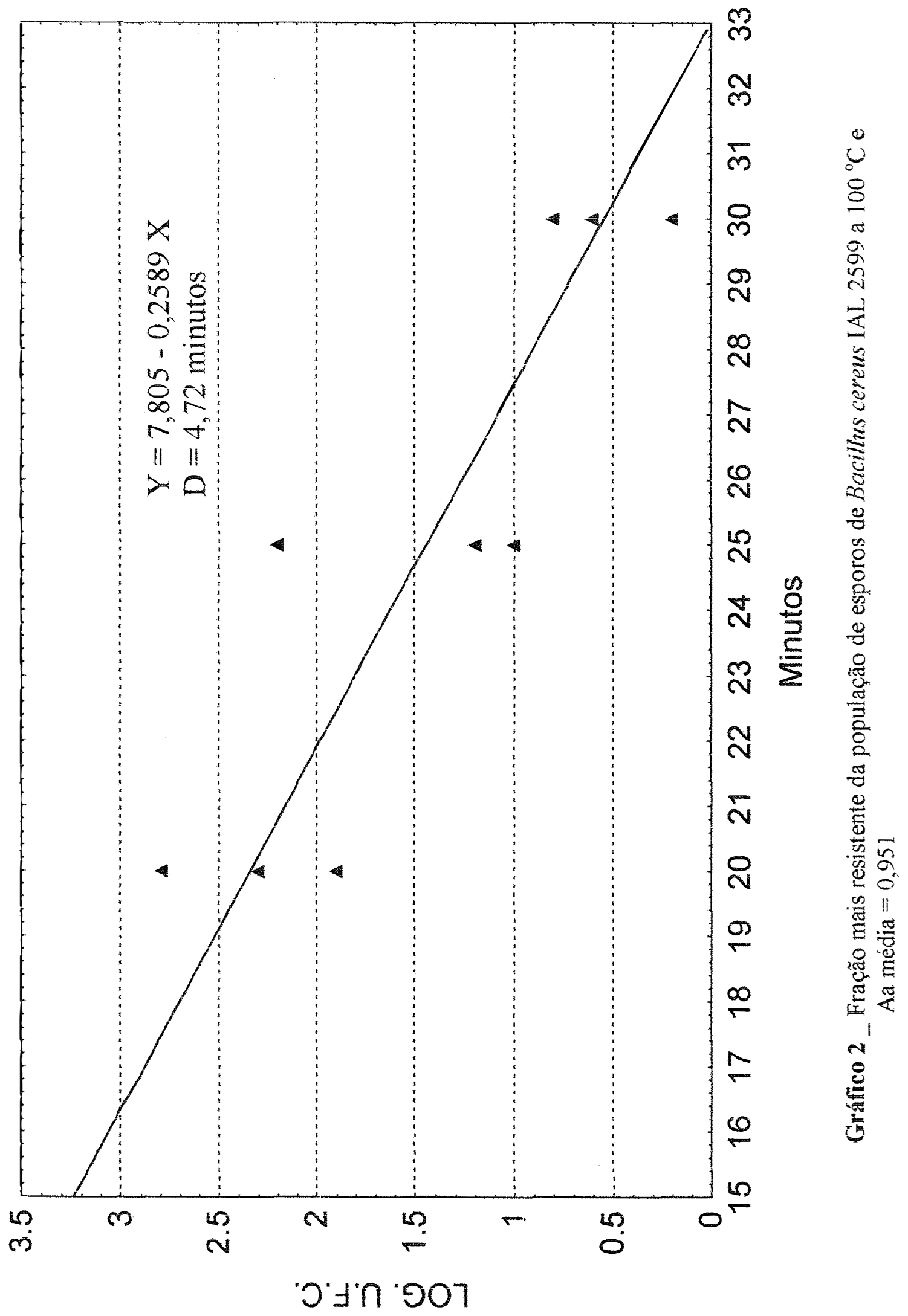




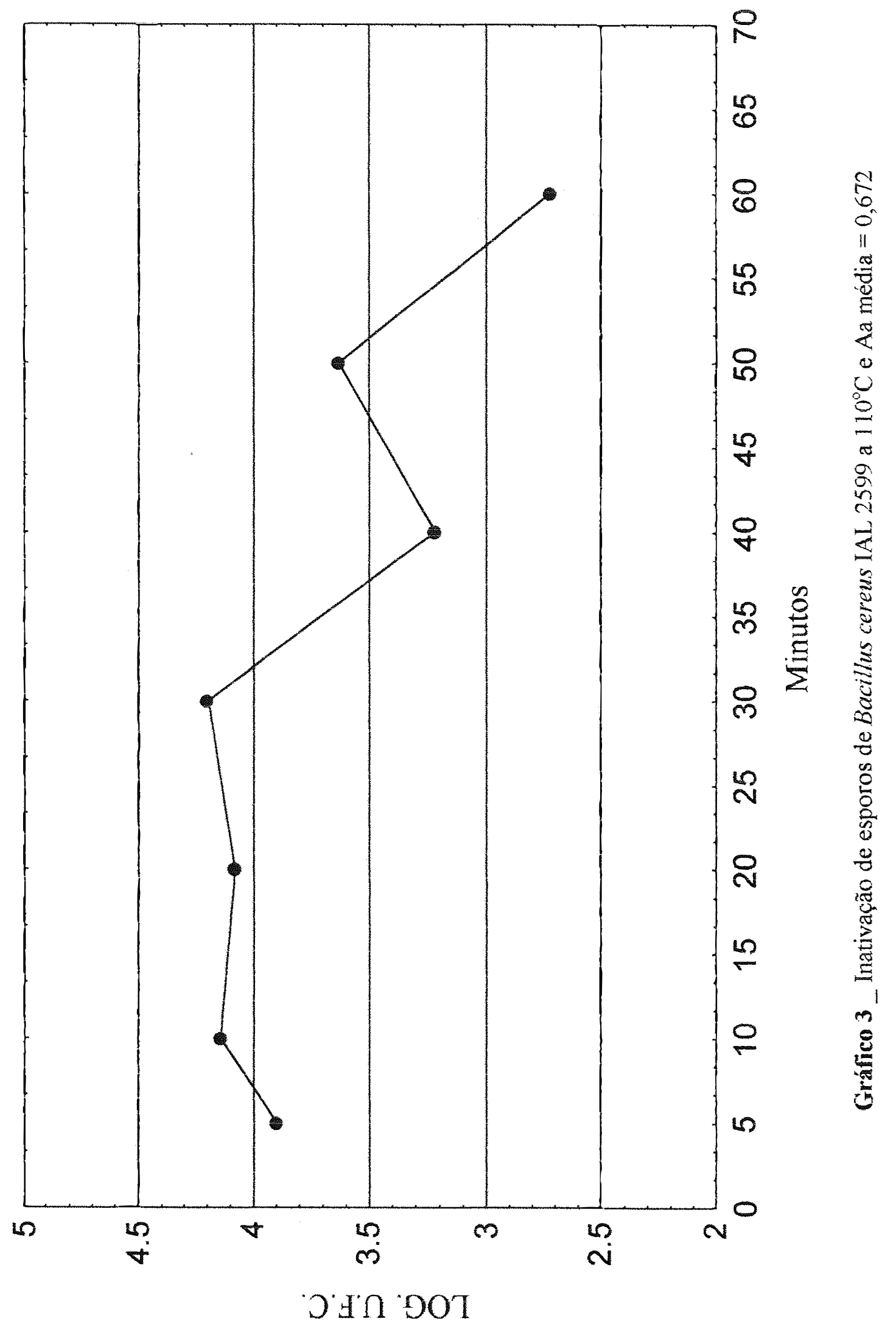




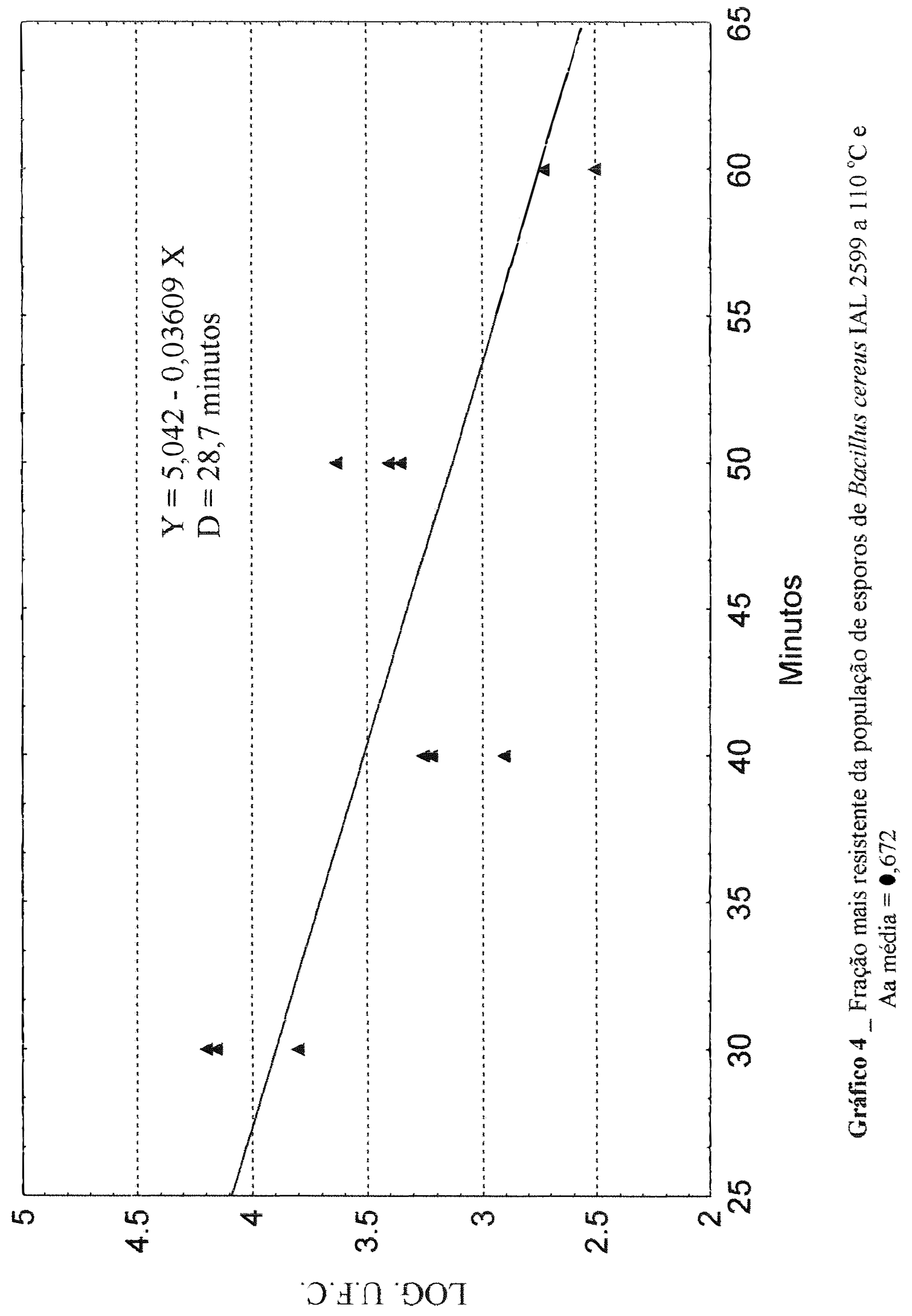




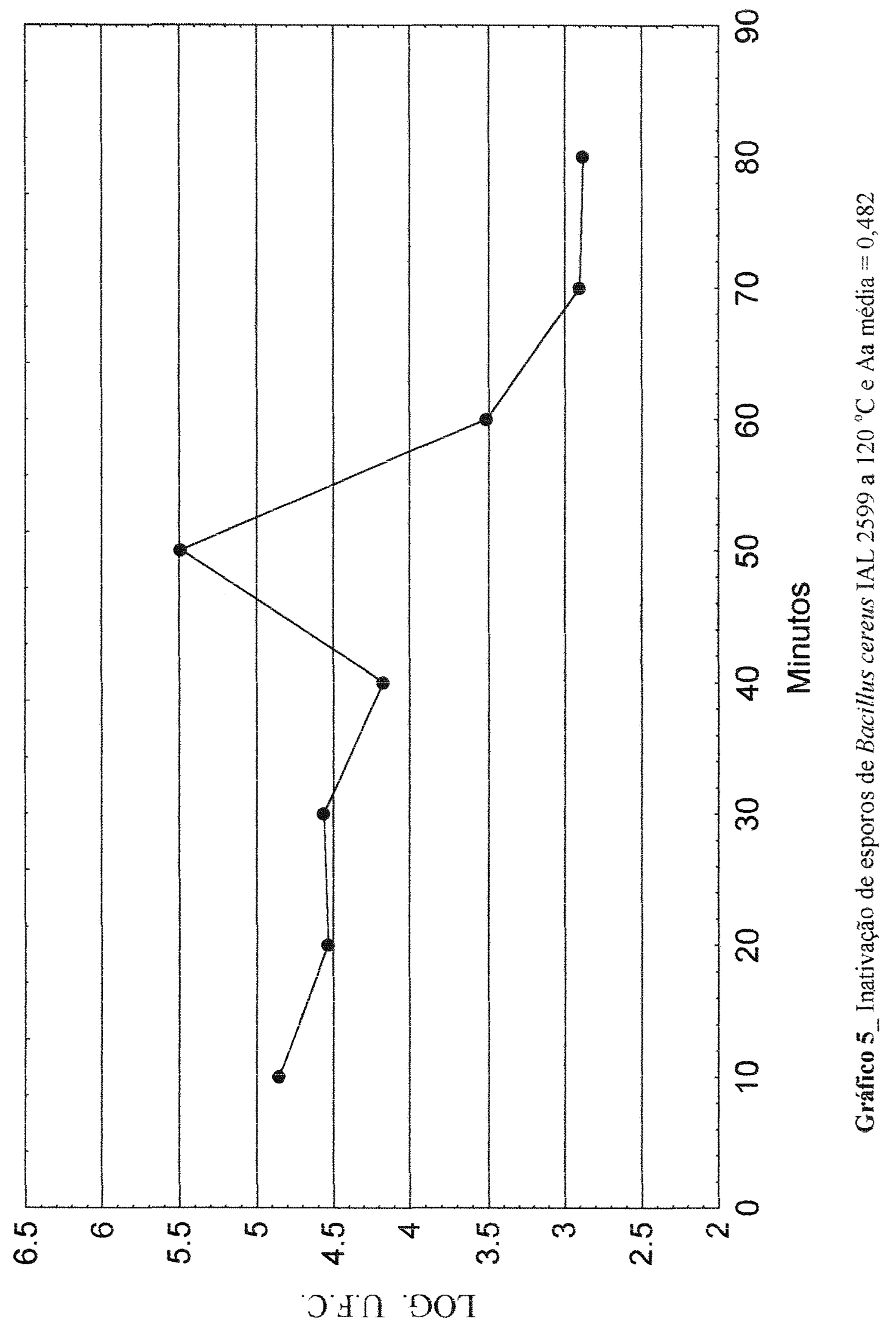




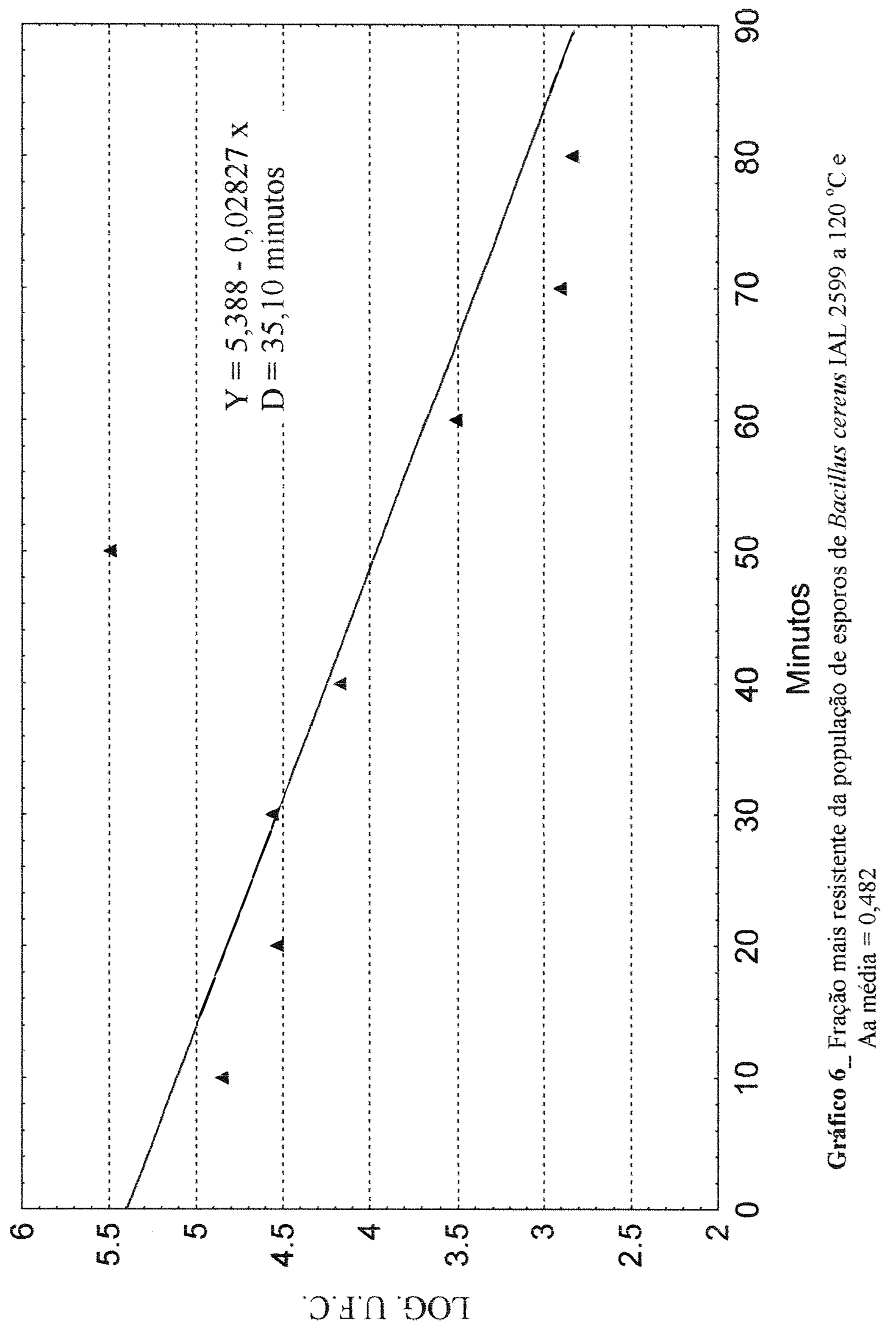




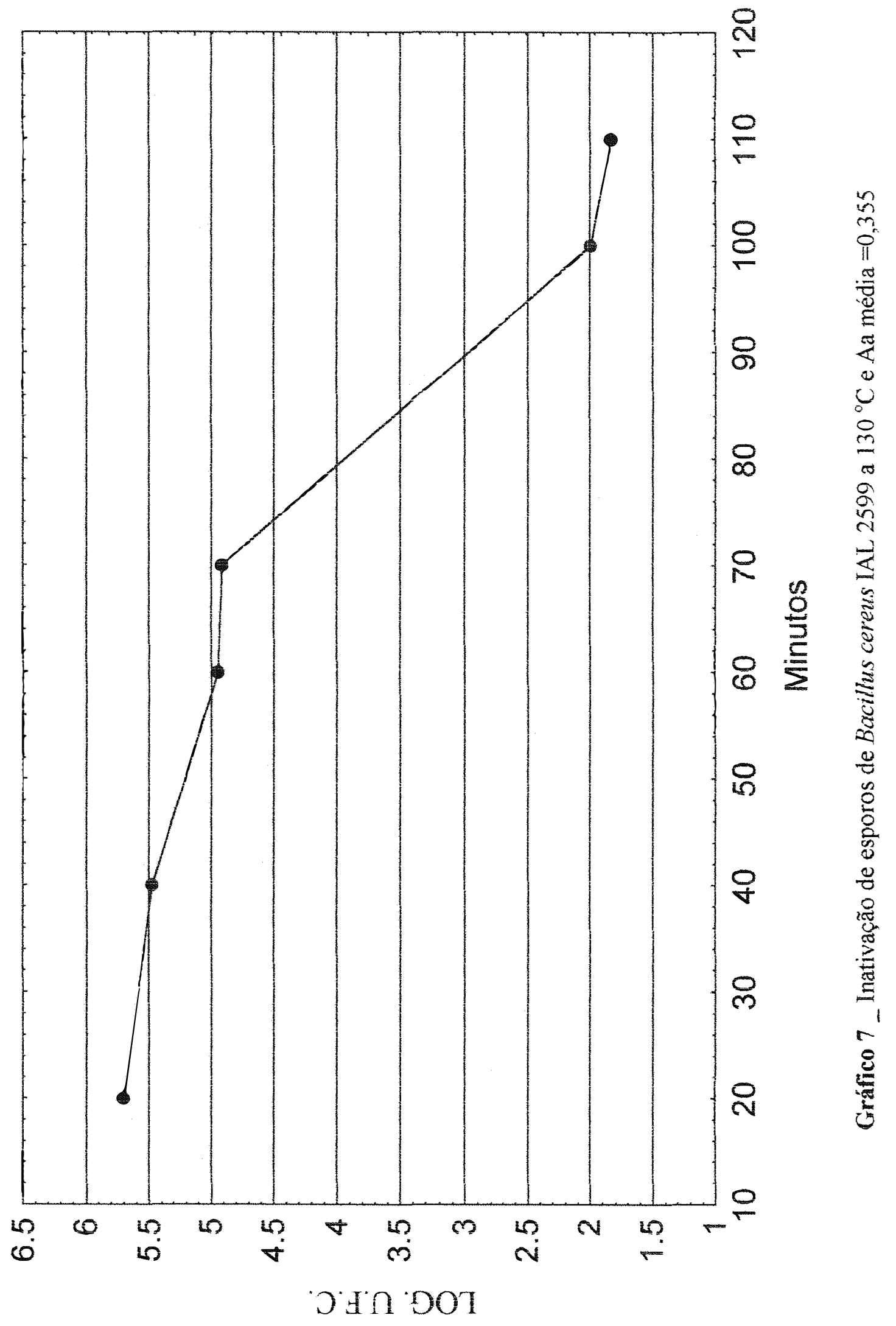




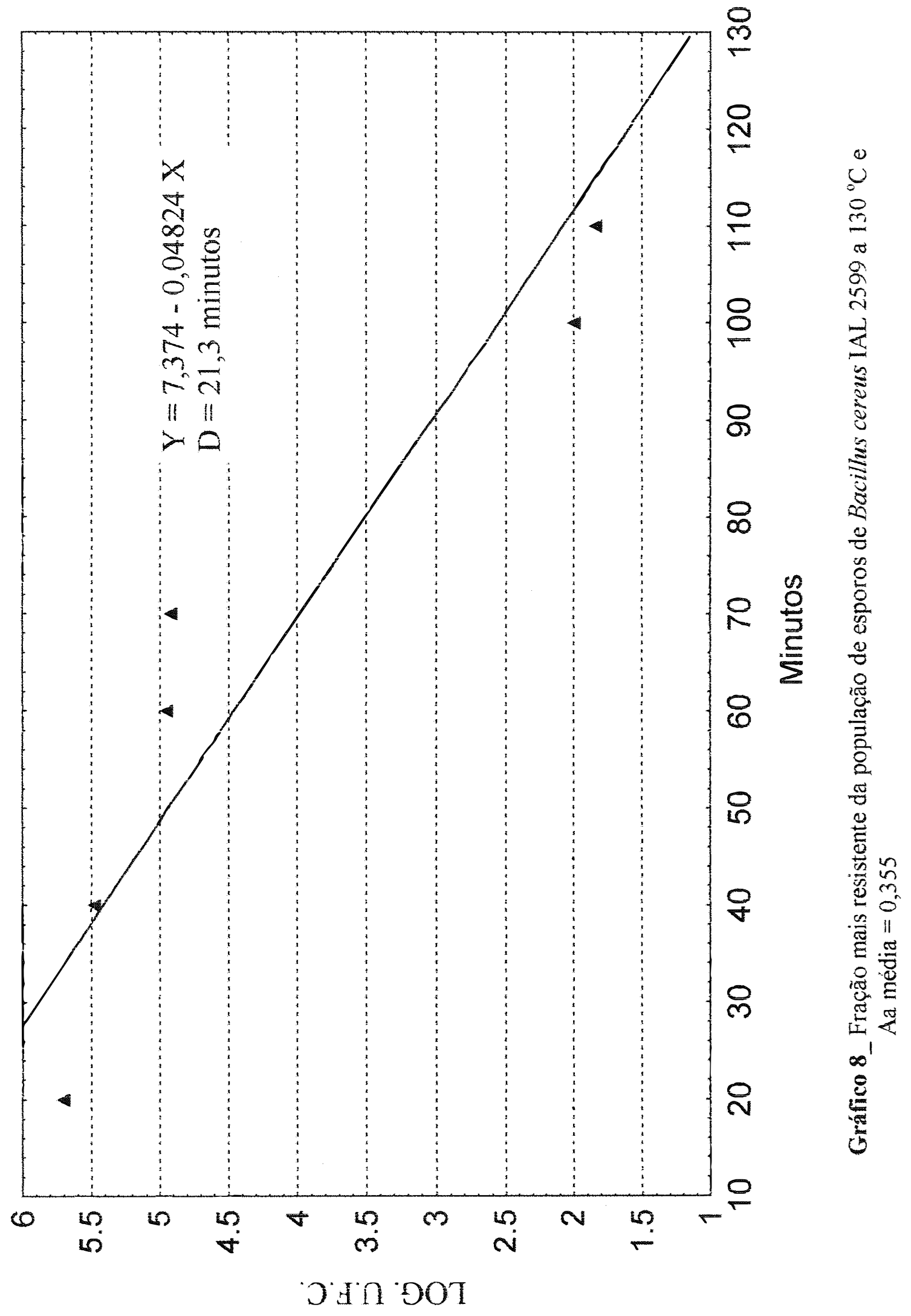




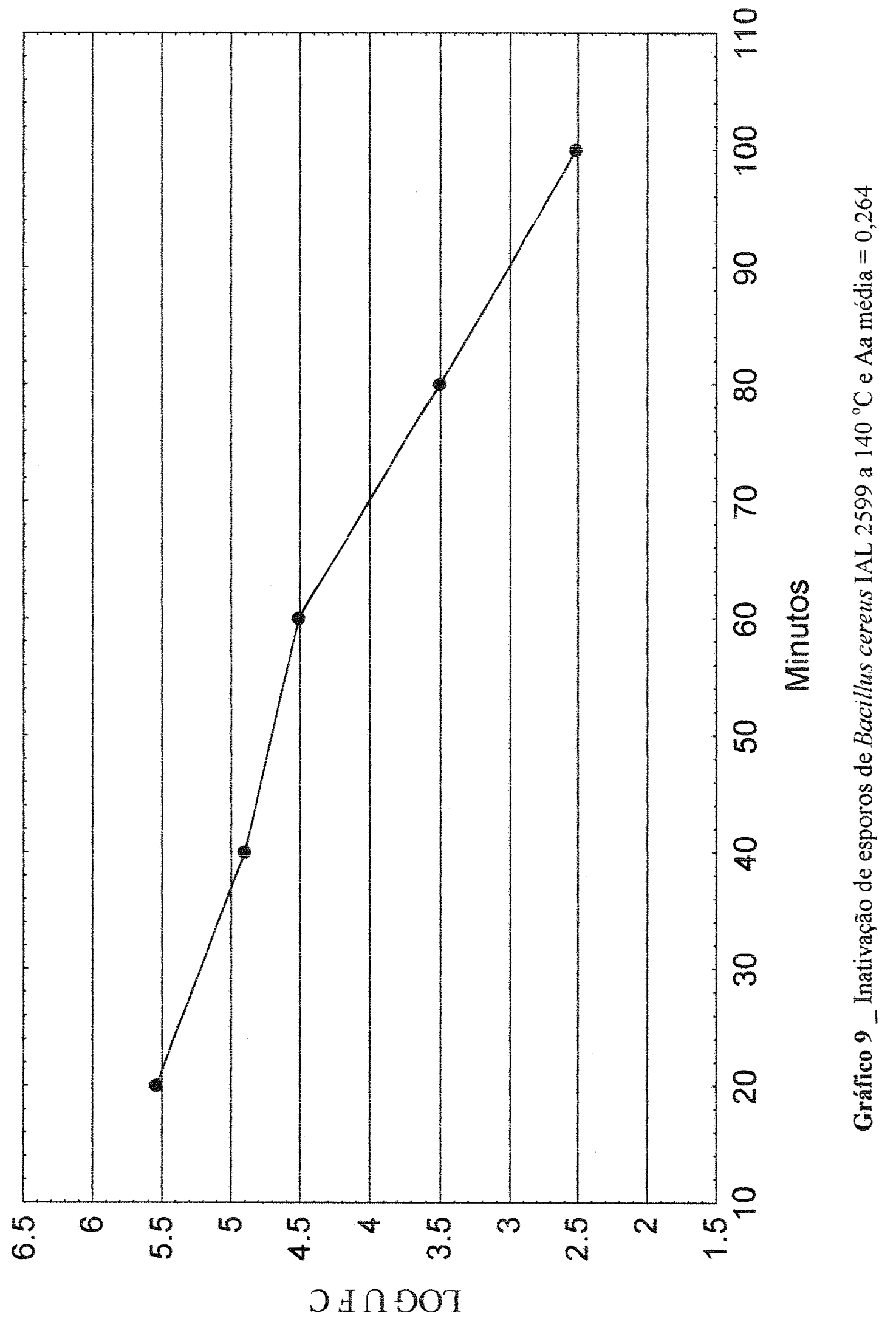




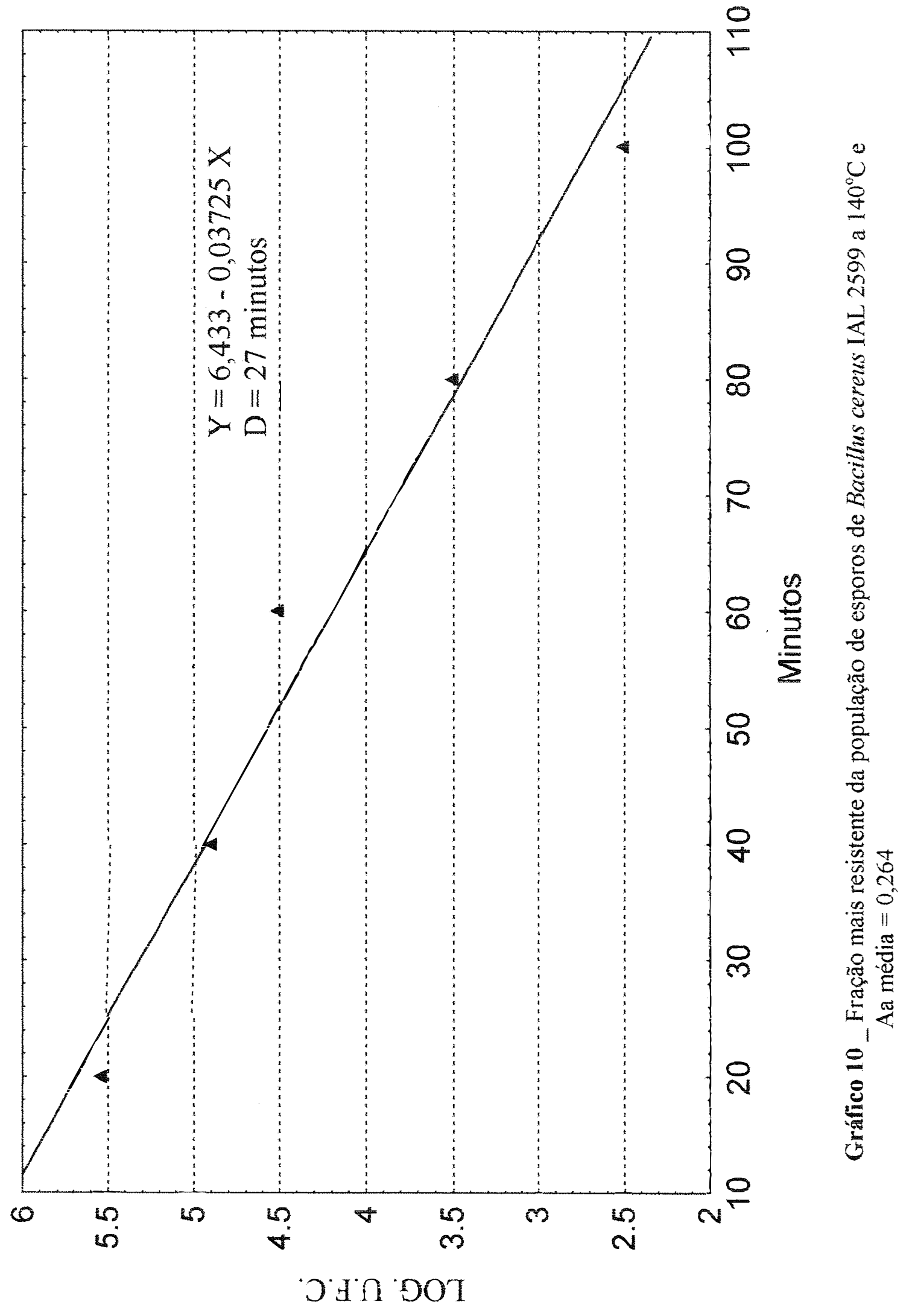




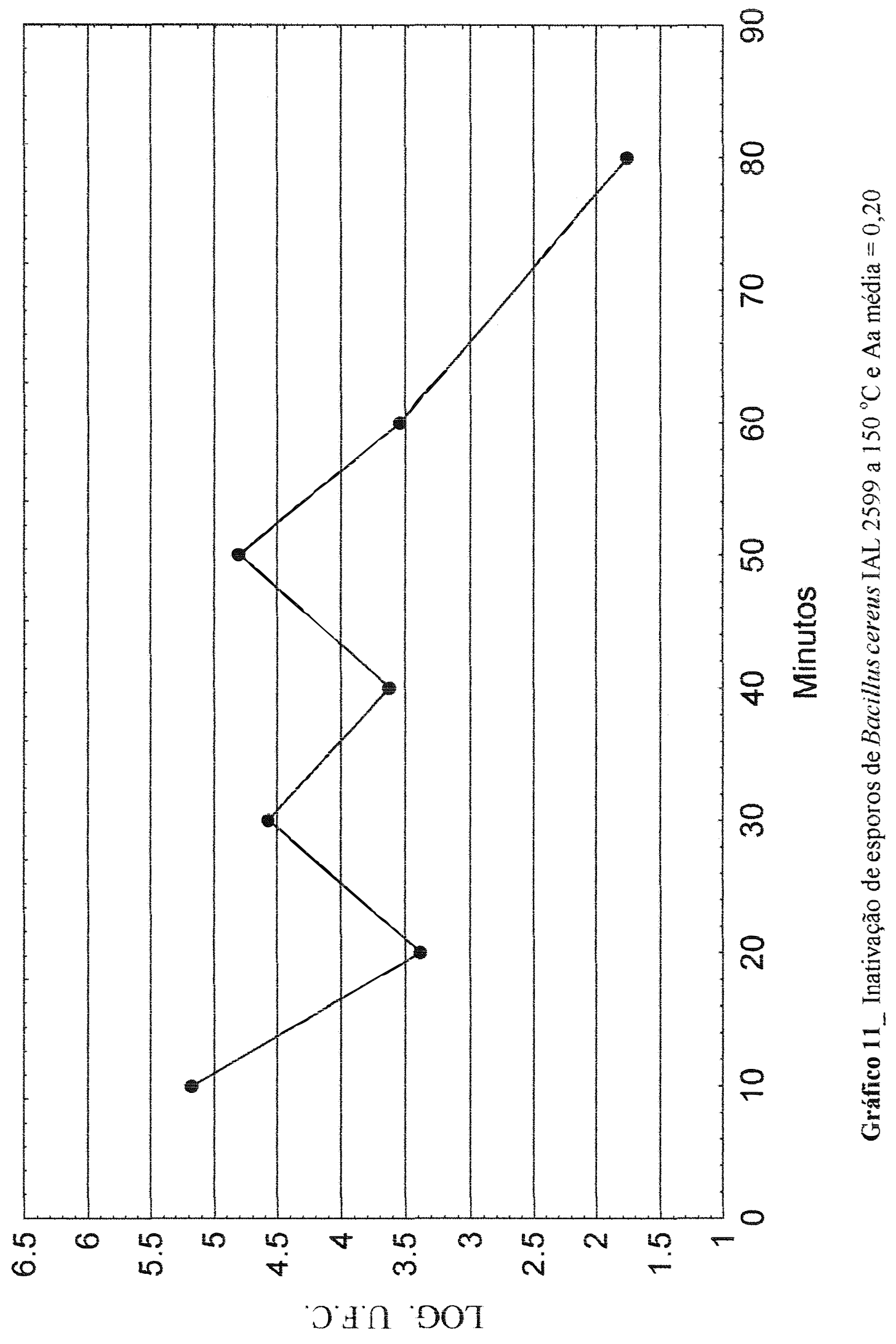




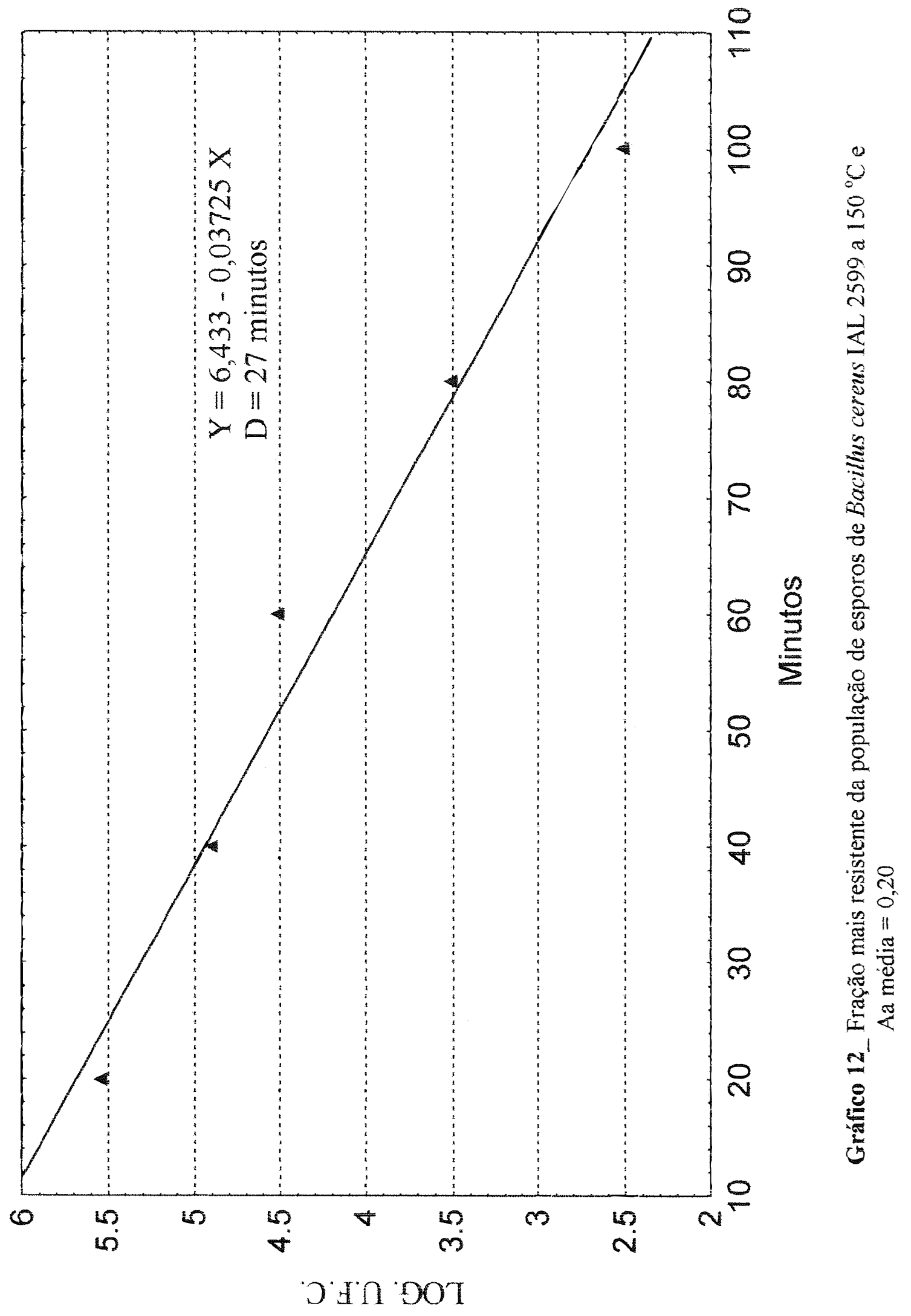




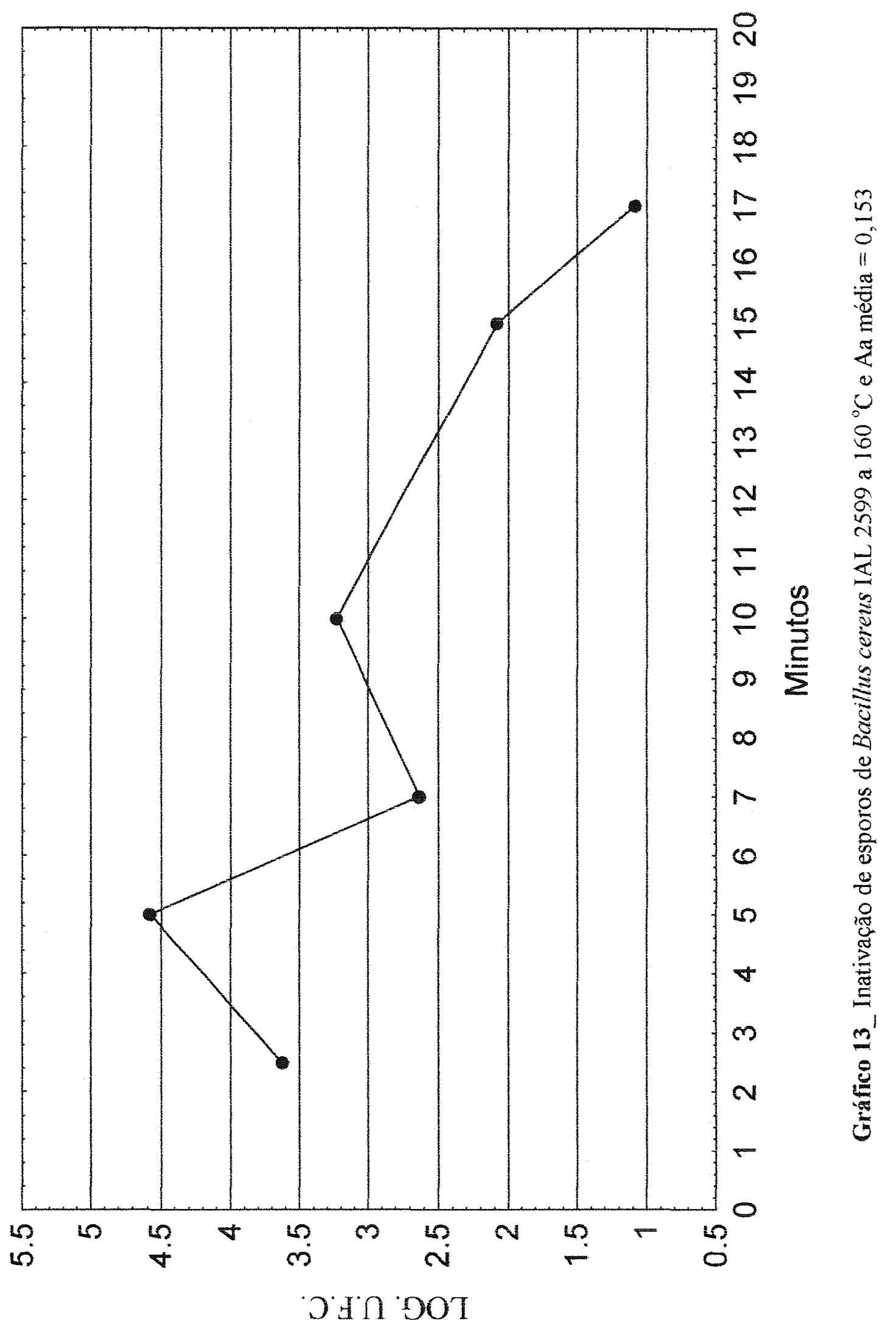




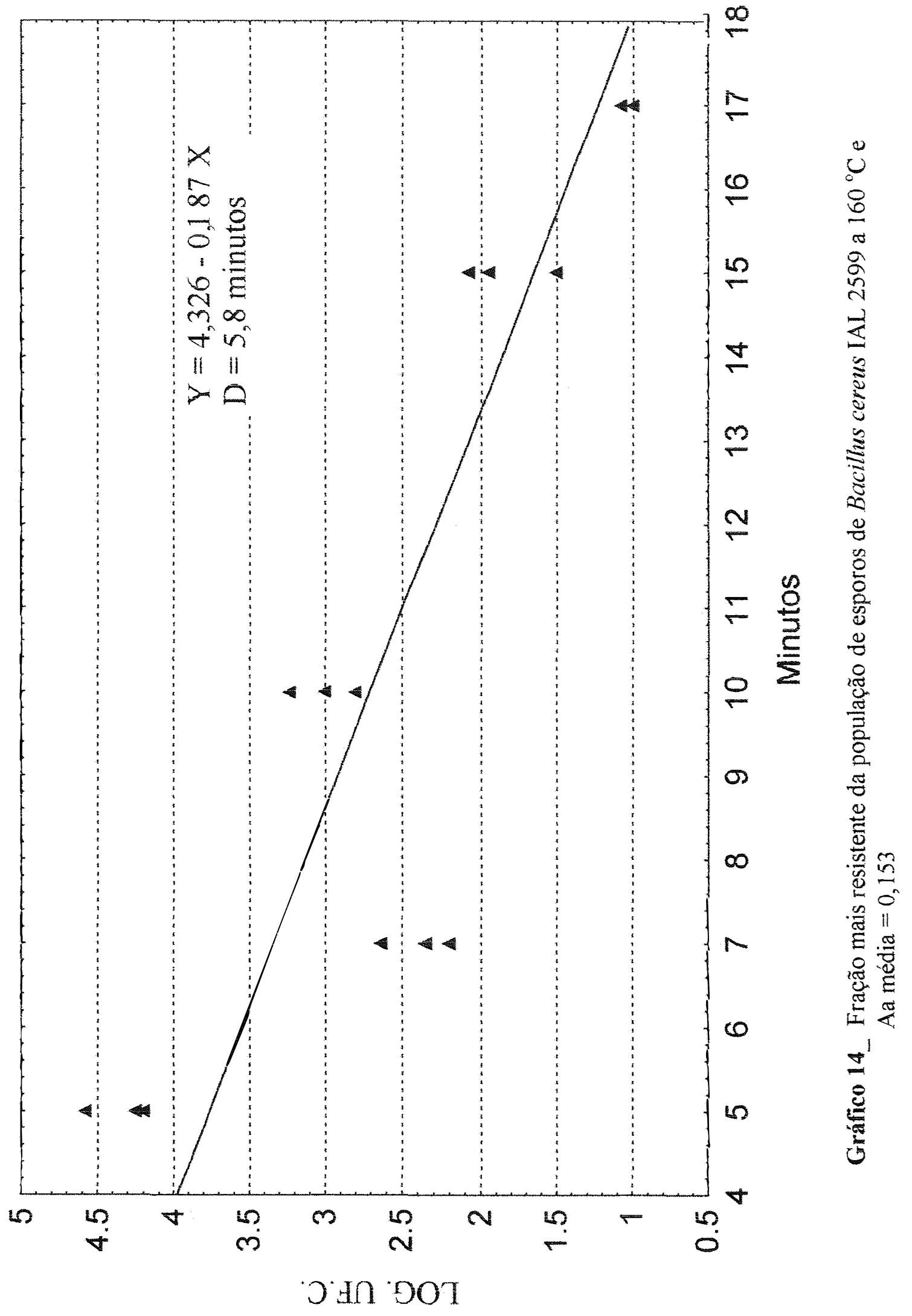




\section{5 _ DISCUSSÃo}

Em pesquisas sobre resistência térmica de esporos de bactérias em ambiente de atividade de água menor que 1,0, a espécie preferencialmente usada é Bacillus subtilis, sendo o Bacillus subtilis var. niger ATCC considerado como padrão de resistência térmica frente ao calor seco. A espécie Bacillus cereus raramente aparece como objeto de estudo neste tipo de inativação térmica (Russel et alii, 1992), embora, seja estudado como contaminante de produtos lácteos em geral.

Pelos resultados obtidos no presente estudo, Bacillus cereus IAL 2599 mostrou resistência térmica consideravelmente alta embora não alcançasse os valores obtidos em estudo similar empregando esporos de Bacillus subtilis var. niger ATCC 9372 (Prado Filho et alii, 1996).

A tabela 8 mostra valores $D$ obtidos por extrapolação gráfica e pela equação de regressão, muito superiores àqueles obtidos pela aplicação direta da formula de Stumbo (1973). Esta formula baseada no logaritmo do número de esporos no inicio e no final do tempo de tratamento, não apresenta precisão suficiente em tratamentos térmicos com grande número de esporos iniciais, pois, o aparecimento de esporos super resistentes causa aumento o valor D a medida que o tempo de tratamento aumenta. Isto foi constatado por outros autores (Hachigian \& Schelinger, 1991; Prado Filho, 1987; Prado Filho 1996). 
Os gráficos 1;3;5;11 e 13 mostram uma variação da resistência térmica., em tempos de tratamento crescentes que não espelham, nem sustentam, a teoria que a inativação térmica de esporos de bactérias transcorre sempre como uma reação de primeira ordem.

A causa de tal inconsistência está na ocorrência de fenômenos de inativação simultâneos ou sucessivos com o aumento dos tempos de tratamento. Estes fenômenos simultâneos ou sucessivos são, por sua vez, a causa do aparecimento de curvas sigmoides, com "ombros" ou "caudas", quando se grafam valores obtidos em experimentos de inativação por calor. Isto é tanto mais notável quando o agente inativante é o calor seco e a população tratada é numericamente grande.

Teoricamente um choque térmico inicial é necessário para ativar esporos de bactérias de modo que germinem e, tal choque deve ativar todos os esporos igualmente e não ter efeito letal algum. Contudo, esta ativação inicial nem sempre é encontrada na prática, mormente, quando o choque térmico é por calor seco com atividade de água menor que 1,0 (Prado Filho 1987; Prado Filho et alii 1996). Isto é explicado pela existência de mecanismos de ativação diferentes, tanto para o calor seco como para o úmido, a baixas e altas temperaturas (Adams \& Busta 1972; Berg \& Sandine 1970). Os gráficos 7 e $9\left(130^{\circ} \mathrm{C}\right.$ e $\left.140^{\circ} \mathrm{C}\right)$ mostram curvas de inativação transcorrendo como uma reação de primeira ordem e que podem ser caracterizadas, com bastante segurança, por um valor D calculado por equação de regressão. Contudo, os demais gráficos, notadamente o gráfico $11\left(150^{\circ} \mathrm{C}\right)$ só permitem uma avaliação de um valor $\mathrm{D}$ quando se estabelece "a priori" os pontos que serão considerados no calculo da equação de regressão (tabelas 1 a 7), o que, por sua vez. introduz um fator subjetivo no calculo deste parâmetro.

Devido ao fato de mecanismos de ativação e inativação simultâneos ou seqüenciais não se mostram constantes em todas as combinações tempo/ temperatura/ atividade de água testadas, estabelecer um valor D caracteristico para cada combinação carece de uma 
objetividade inquestionável. Assim os valores D encontrados (tabela 8) servem como indicadores, não determinantes, da resistência térmica de frações hiper-resistentes em populações muito numerosas maior que $10 \mathrm{E}+10$ esporos inoculados as quais não são comuns nas condições praticas usuais.

Considerando os resultados obtidos e, tomando como referencial o maior número de esporos hiper-resistentes detectados com um mínimo tempo, constata-se que a ocorrência dos mesmos é mínima como mostra a tabela 9 . Os valores indicam a ocorrência de esporos hiperresistentes em todas as combinações estudadas, é menor que um por 285.000 .

\begin{tabular}{|c|c|c|c|}
\hline Temperatura & $\mathrm{Aa}$ & Tempos de tratamento & Esporos viáveis por esporos \\
\hline${ }^{\circ} \mathrm{C}$ & media & (minutos) & inoculados \\
\hline 100 & 0,951 & 10 & 1 por $2,60 \mathrm{E}+5$ \\
\hline 110 & 0,672 & 30 & 1 por $1,10 E+7$ \\
\hline 120 & 0,482 & 50 & 1 por $5,52 E+5$ \\
\hline 130 & 0,355 & 20 & 1 por $2,85 E+5$ \\
\hline 140 & 0,264 & 20 & 1 por $5,00 E+5$ \\
\hline 150 & 0,20 & 10 & 1 por $1,10 E+6$ \\
\hline 160 & 0,153 & 5 & 1 por $4,50 E+6$ \\
\hline
\end{tabular}

* Â pressão ambiental média de $715 \mathrm{~mm} \mathrm{Hg}$.

Tabela 9 _ Ocorrência de esporos hiper-resistentes em todas as combinaçöes estudadas

A maior ocorrência de esporos hiper-resistentes mostrada na tabela 9 é de 1 por 285.000 esporos inoculados, isto á $130^{\circ} \mathrm{C}$ e $\mathrm{Aa}=0,355$, valores próximos àqueles em que foi determinado o maior valor D para Bacillus subtilis var. niger ATCC 9372 empregando o método 
da regressão linear (Prado Filho et alii, 1996), que, entretanto forneceu um valor cerca de uma potência da dez maior que o determinado neste estudo com Bacillus cereus IAL 2599.

Os valores $\mathrm{D}$ apresentados na tabela 8 não mostram uma definição marcante de um valor $\mathrm{D}$ notavelmente maior que os demais nas temperaturas $110^{\circ} \mathrm{C} ; 120^{\circ} \mathrm{C} ; 130^{\circ} \mathrm{C}$ e $140^{\circ} \mathrm{C}$, faixa em que a resistência térmica dos esporos é bastante alta, porém similar, para um inoculo com grande número de esporos.

Para fins, eventualmente, práticos, um número muito alto de esporos em um bioindicador, para processos térmicos, pode apresentar o inconveniente de uma camada muito densa, no portador, toma-se quebradiça com o tratamento podendo levar à perda de material e, consequentemente alteração da contagem da UFC viáveis (Grisotto, 1992) ou, ainda, apontar não eficiência do processo devido ao anormal de esporos hiper-resistentes.

O aparecimento de frações hiper-resistentes é conseqüência esperada da distribuição gaussiana normal da resistência numa população de esporos e, a probabilidade de detectá-las é tanto maior quanto maior é população considerada.

Tomar os valores $\mathrm{D}$ dessas frações hiper-resistentes como paràmetros para tratamentos por calor seco empregando vapor superaquecido como no estudo em pauta, pode significar considerar um fator de segurança demasiado alto, exagerado mesmo. Neste caso, um tal fator, em condições práticas, poderia significar um tratamento desnecessário para os materiais ocasionando eventual perda de qualidade, desperdício de energia e, aumentando o tempo de operação de equipamentos.

A influência dos fenômenos de ativação simultâneos éou seqüenciais e, da não homogeneidade de populações de esporos devido a distribuição gaussiana normal da resistência em estudos de resistência térmica foi discutida e documentada por numerosos autores (Adams \& Busta, 1972; Alderton et alii, 1970; Berg \& Sandine, 1970; Bond et alii, 1971; Edward \& Busta, 
1965; Molin \& Östlund, 1975; Peter et alii, 1977; Prado Filho, 1987; Prado Filho et alii, 1996; Puleo et alii, 1978; Sharpe \& Betkash, 1977; Schull et alii, 1963; Stumbo, 1973; Toda, 1970) e mostra a complexidade do assunto ainda não está esgotado.

Os resultados obtidos apontam claramente para o fato de o número de esporos de Bacillus cereus IAL 2599, em bioindicadores para tratamento térmico com calor seco, poder ser bem menor que o empregado no presente estudo.

Portadores de esporos de Bacillus cereus IAL 2599 a serem usados como bioindicadores em processos térmicos por calor seco empregando vapor superaquecido ou, mesmo, ar quente, no intervalo $120-140^{\circ} \mathrm{C}$, pode, com bastante segurança, conter um número de esporos limitado a N $10 \mathrm{E}+6$ por unidade. Processos térmicos capazes de reduzir de seis potências de dez a população contaminante do objeto processado, estão dentro do âmbito pratico preconizado para microrganismos não patogênicos em alimentos como Bacillus stearothermophilus ou Bacillus coagulans, quando o processo é por calor úmido.

Quando o processo é por calor seco empregando ar quente, cuja Aa no intervalo estudado é muito menor que 0,100 (Contiero Prado Filho, 1987) um bioindicador portando $\mathrm{Nx}$ 10 E+6 esporos de Bacillus cereus IAL 2599 apresenta uma margem de segurança adicional, pois, a resistência de esporos à Aa muito baixa, è sensivelmente menor que à valores de Aa intermediários.

Os resultados do presente estudo demostraram, mais uma vez, que o, valor $Z$ não pode ser considerado nos experimentos com calor seco em valores de Aa intermediários, pois, à uma elevação constante da temperatura não corresponde uma aceleração de uma potência de dez na velocidade de inativação dos esporos. No caso presente uma elevação da temperatura significa uma alteração nas propriedades do agente térmico, com reflexos diretos na sua eficiência esterilizante (Prado Filho, 1987; Prado Filho et alii 1996). 
A impossibilidade da determinação de um valor $Z$ obriga que, em processos térmicos com calor seco com Aa intermediárias considere-se os resultados obtidos à uma dada temperatura como individuais e caracteristicos para o conjunto temperatura-bioindicadoratividade de água, não sendo extrapoláveis para outras situações em que haja variação de um dos componentes do conjunto.

Um cuidado adicional que deve ser observado é levar em conta que bioindicadores artefatos de laboratório nem sempre refletem, na sua produção e manuseio, as condições a que estão submetidas as populações nativas dos objetos a serem tratadas.

Em casos excepcionais podem ocorrer, sob condições naturais, esporos hiperresistentes que sobrevivem a tratamentos tão prolongados como 14,4 h (Puleo et alii 1981) ou, mesmo, 54h (Reynolds \& Favero, 1975).

Contudo, nos casos supracitados não foram calculados valores $D$, e sim, apontados sobreviventes após os tempos prolongados de tratamento térmico.

Com base nesse conceito de resistência e não na determinação de um valor $\mathrm{D}$ para uma fração mais resistentes da população, é que apresentamos os valores da tabela 9 como parâmetros básicos da resistência térmica de esporos de Bacillus cereus IAL 2599 ao tratamento com vapor superaquecido no intervalo $100^{\circ} \mathrm{C}$ a $160^{\circ} \mathrm{C}$.

Embora não ocorrendo a maior resistência no intervalo $\mathrm{Aa}=0,40 \mathrm{a} \mathrm{Aa}=0,20$ que é o que ocorre mais comumente no tratamento térmico de esporos de bactérias por calor seco (Angellotti et alii, 1968; Murrel \& Scott, 1966; Prado Filho 1987; Prado et alii 1996), os resultados obtidos apontam que neste intervalo de $\mathrm{Aa}$, a resistência dos esporos é notavelmente maior que em valores de Aa próximos de 1,0 ou menores que 0,20 , sendo que a maior ocorrência de hiper-resistentes na população tratada com minimo tempo de tratamento se dá aos 20 minutos de tratamento a $130^{\circ} \mathrm{C}$ e $\mathrm{Aa}=0,355$. 


\section{6 _ CONCLUSÕES}

Com exceção do experimento a $140^{\circ} \mathrm{C}$ e $\mathrm{Aa}=0,264$ forarn observados em todos os tratamentos a ocorrência de fenômenos simultâneos e seqüenciais de ativação dos esporos de Bacillus cereus IAL 2599.

Em todas as temperaturas foram detectados esporos hiper-resistentes aos tratamentos aplicados, sendo sua maior ocorrência a $120^{\circ} \mathrm{C}$ e $\mathrm{Aa}=0,482$, e ao mesmo tempo a formula tradicional, para o calculo de resistência térmica proposta por Stumbo (1973) mostrou-se inconsistente com os resultados numéricos encontrados neste estudo.

Os valores D de uma fração mais resistente da população de esporos calculada por equação de regressão apoiada em tempos escolhidos de tratamento, embutem um fator subjetivo que pode levar a uma superestimação de tratamentos térmicos recomendados.

Com base no número máximo de esporos viáveis detectáveis após um tempo mínimo de tratamento, os tempos de tratamento indicados para processos com calor seco e emprego de esporos de Bacillus cereus como bioindicador foram $10 \mathrm{~min}$.; $30 \mathrm{~min}$.; $50 \mathrm{~min}$.; 20 min.; 20 min.; 10 min.; 5 minutos respectivamente para $100^{\circ} \mathrm{C} ; 110^{\circ} \mathrm{C} ; 120^{\circ} \mathrm{C} ; 130^{\circ} \mathrm{C} ; 140^{\circ} \mathrm{C}$; $150^{\circ} \mathrm{C}$ e $160^{\circ} \mathrm{C}$ 
Os valores obtidos só são confiáveis para conjunto específico de temperaturabioindicador-atividade de água, não sendo extrapoláveis para situações em que haja variação em quaisquer um dos componentes do conjunto.

Embora não especificamente maior dentro do intervalo $\mathrm{Aa}=0,40 \mathrm{a} \mathrm{Aa}=0,20$, as resistências constatadas são sensivelmente maiores a Aa intermediárias do que em valores de Aa próximos a 1,00 ou menores que 0,20 . 


\section{7 _ REFERÊNCIAS BIBLIOGRÁFICAS}

ADAMS, D.M; BUSTA, F.F. Ultra high temperature activation of low temperature Bacillus subtilis spores germination system. Applied Microbiology, Washington, v. 24 p. 418-423. 1972.

ALCOCK, S. Evaluation of heat resistance of Clostridium sporogenes following heat shock . Food Microbiology, v.1, p. 39 - 41, 1984.

ALDERTON, G. ; SNELL, N. Chemical states of bacterial spores; heta resistance and its kinetics of intermediate water activity. Applied Microbiology, v.19, p. $562-72$. 1970

ALDERTON, G., CHEN, J. K. ; ITO, K. A. Resistance forms of Clostridium boulinum 62 A spores over the water activity range 0 to 0,9 . Applied and Environmental Microbiology, v.30 p. $51-5,1980$.

ALDERTON, G.; ITO, K. A.; CHEN, J. K. Chemical manipulation of the heat resistance of Closiridium boiulinum spores. Applied and Environmental Microbiology, v.31 p. $492-8,1976$.

ANGELOTTI , R.; MARYANSKI , J. H.; BUTLER, T. F.; PEELER, J. T.; CAMPBELL, J.E. Influence of spores moisture content of the dry heat resistance of Bacillus subtilis var. niger. Applied Microbiology, v. 15 p. $735-45,1968$.

BAYLISS, C. E.; WAITES, W. M. Effect of simultaneous high intensityultraviolet irradiation and hydrogen peroxide on bacterial spores. Journal of Food Technology, v. 17 p. $467-70,1982$.

BEAMAN, T. C.; GERHARDT, P. Heat resistance of bacterial spores correlated with protoplast dehydration, mineralization, and thermal adaptation. Applied and Environmental Microbiology, v.52 n. 6 p. $1242-6,1980$. 
BERG, R. W.; SANDINE, W. E. Activation of bacterial spores. A review. Joumal Milk. Food Technology. v. 33 p. $435-41,1970$.

BOND, W. W.; FAVERO, M. S. Thermal profile of a Bacillus species (ATCC 27380) extremely resistant to dry heat. Applied Microbiology, v. 29 p. 859 -60, 1975.

BOND, W. W.; FAVERO, M. S.; KORBER, M. R. Bacillus sp. ATCC 27380 a spore with extreme resistance to dry heat. Applied Microbiology, v. 26 n.4 p. 614 $-6,1973$.

BOND, W. W.; FAVERO, M. S.; PETERSEN, N. J.; MARSHAL, J. H. Relative frequency distribuition of $D_{125}$ values for spores isolates from Mariner - Mars 1969 space craft. Applied Microbiology, v. 21, p. $32-6,1971$.

BRANNEM J. R.; GASRT, D. M. Dry heat inactivation of bacillus subtilis var. niger spores as a function of relative humidity. Applied Microbiology, v. 23 p. $1125-30,1972$.

BROWN, K. L. Use of a computer data file for storage of heat resistance data on bacterial spores. Journal of Applied Bacteriology, v. 65 p. 49 - 54, 1988.

BRUCH, K. M.; SMITH, W. F. Dry heat resistance of spores of Bacilus subtilis var. niger on Kapton and Teflon film at high temperatures. Applied Microbiology, v.16 p. $1841-6,1968$.

CHUMNEY, R. K. ; ADAMS , D. M. Relationship between the increases sensitivity of heat injured Cllostridium perfrigens spores to surface active antibiotics and to sodium chloride and sodium nitrate. Journal of Applied Bacteriology, v. 49 p. 55 - 63, 1968.

COLLLIER, C. P.; TOWNSED, T. The resistance of bacterial spores to superheated steam. Food Technology, v. 10 p. $477-81,1.956$.

COLLINS, C. H.; LYNE, P. M. Microbiological Methods. Butterworths, 1970. 454 p. CONTIERO, J. Resistência térmica de conidiospóros de Aspergillus parasiticus Speare ao calor seco: Desenvolvimento de equipamentos e ensaios. Piracicaba 1984, 93 p. ( Mestrado - Escola Superior de Agricultura Luiz de Queiroz / USP ).

CONTIERO, J.; PRADO FILHO, L.G. Resistência térmica de conidiosporos de Aspergillus parasiticus Speare ao calor seco. Ciência e Tecnologia de Alimentos, $\mathrm{V}$. 7 N. 7 p.50-62. 1987 
DRUMOND, D . W.; PFLUG, I. J. Dry heat destruction of Bacillus subtilis on surface effect of humidity in an open system. Applied Microbiology, v 20 p. 805-9, 1970.

EMBORG, C. Inactivation of dried bacteria and bacterial spores by means of gamma irradiation at high temperature. Applied Microbiology, v. $27: 830$ - 3, 1974.

ETOA, F. X.; MITCHIELS, L. Heat induced resistance of Bacillus stearothermophilus spores. Letters in Applied Microbiology, v. 6 p. 43 - 5, 1974.

FEEHERRY, F. E.; MUNSEY, D. T.; ROWLEY, D. B. Thermal inactivation and injury of Bacillus stearothermophilus spores. Applied and Environmental Microbiology, v 53 n.2, p. 365 - 70, 1987.

FISHER, D. A.; PFLUG, I. J. Effect of combined heat and radiation on micrbiology destruction. Applied and Environmental Microbiology , v. 33 p. 1170 - 6, 1970.

FOX, K.; PFLUG, J. J. Effect of temperature and gas velocity on the dry heat destruction rate of bacterial spores. Applied Microbiology, v. 6 n. 2, p. 343-8, 1968.

FOX, K.; EDER, B. Comparisson of survivor curves of Bacillus subtilis spores subjected to wet and dry heat. Journal of Food Science, v.34, n. 6, p. $518-20$, 1969.

GRISOTTO, R. Construção e testes de câmara para tratamento de esporos de microrganismos. Piracicaba,1992. 72 p. ( Mestrado Escola Superior de Agricultura Luiz de Queiroz / USP ).

HACHIGIAN, J.; SCHELINGER, R. J. Analysis of quantal response data from bacterial destruction studies in sterilization : the Stumbo estimate is biased. Journal of Applied Bacteriology, v. 71 p. 460 - 66, 1991.

HAN - BONG - HO. Abttötung von mikrorganismen auf festen oberfläthcen. Karlsruche, Fakultat für chemieeigenienrwessen, Univ. ( TH .) 90 p. (Tese Doutoramento).1977 HARNULV, B. G.; JOHANSSON, M.; SNYGG, B. G. Heat resistance of Bacillus stearothermophilus spores at different water activities. Journal of Food Science, V. 42 p. $91-3,1977$.

HOFFMAN, R. K.; GAMBILL, V. M.; BUCHANAN, L. M. Effect of cell moisture on the thermal intivation rate of bacterial spores. Applied Microbiology, v. 16 p. 1240 $-1,1968$. 
KAHOURY, D. H.; LOMBARD, S. J.; SPLECKY, R. A. Perturbation of the heat resistance of bacterial spores by sporulation temperature and ethanol Current Microbiology, v. 15 p. $7-9,1.987$.

KING JUNIOR, A. D.; BAINE, H. G.; ALDERTON, G. Non logarithmic death rate calculation for $B$. fulva and other microrganisms. Applied and Environmental Microbiology, v. 37 p. $596-600,1969$.

LEADER, S. Comparison of the resistance to hydrogen peroxide of wet and dry spores of Bacillus subtilis 5 A 22. Journal of Food Technology, v. 19 p.695-702 1984.

LYNCH, D. J.; POTTER, N. N. Effects of organic acids on thermal inactivation of Bacillus stearothermophilus and Bacillus coagulans spores in Frankfurter emulsion slurry. Journal of Food Protection, v. 51 , n. 6 p. $475: 80,1988$.

MALLADIS, C. G.; SCHOLEFIELD, J. Determination of the resistance of spores using a solid heating block system. Journal of Applied Bacteriology, v. 59 p. 407 - 411, 1985

MALLADIS, C. G.; SCHOLEFIELD, J. Relation of the heat resistance of spores to chemical composition on structure. I. Relation to core components. Journal of Applied Bacteriology, v. 62 p. $65-9,1987$.

MOLIN, G. Inherent genetic differences in dry heat resistance of some Bacillus spores. In: BARKER, A. N., ed. Spore Research, Academic Press, p. 487 - 500, 1987.

MOLIN, G. Inactivation of Bacillias subtilis spores in dry system at low and high temperature. Journal General Microbiology, v. 101 p.: 227 - 31, 1977 b

MOLIN, G.; ÖSTLUND, K. Dry heat inativation of Bacillus subtilis spores by means of infra - red heating. Antonie Van Leeuweenhoek, v. 41, p. 329 - 35 , 1976.

MOLIN, G.; ÖSTLUND, K. Dry heat inactivation of Bacillus subtilis var. niger spores with special reference to spore density. Canadian Journal Microbiology, v. 22 p. $359-63,1975$

MORTON, R. D.; SCOTT, V. N.; BERNARD, D. T.; WILEY, R. C. Effect of heat and $\mathrm{pH}$ on toxigenic Clostridium butyricum. Journal of Food Science, v. $55, \mathrm{n} .6 \mathrm{p}$. $1725-7,1990$.

MURREL, W. G.; SCOTT, W. J. The resistance of bacterial spores at various water activities. Journal of General Microbiology, v. 43, p. $411-25,1966$. 
ODLANG, T. E.; CAPUTO, R. A.; GRAHAM, G. S. Heat resistance and population stability of lyophilized Bacillus subtilis spores. Applied and Environmental Microbiology, v. 41, p. $3374-7,1981$.

OXBORROW, G. S.; PLACENCIA, A. M.; DANIELSON, J. W. Effects of temperature and relative humidity on biological indicators used for ethylene oxid sterilization. Applied and Environmental Microbiology, v. 45, p. 46-9, 1982.

PEELER, J. T.; REYES, A. L.; GRAWFORD, A. J.; WEHBY, A.J.; CAMPBELL, J. E. Thermal resistance of Bacillus subtilis var. niger in closed system. Applied and Environmental Microbiology, v.33, p. $52-8,1977$.

PFEIL, C. G.; PFLUG, I. J.; NICHOLAS, R. C.; AUGUSTIN, J. A. L. Effect of various gas atmosphere on destruction of microrganism in dry heat. Applied Microbiology, v. 15, p. $120-4,1967$.

PFLUG, I. J. Thermal resistance of microrganism to dry heat design of apparatus, operational problems and preliminary results. Food Technology, v.14, p. 483-7, 1960.

PRADO FILHO, L. G. Estudo dos parâmetros termodinâmicos da inativação de esporos de Bacillus subtilis var. niger por calor seco. Revista Brasileira de Tecnologia, v.6, p. $77-82,1975$ a.

PRADO FILHO, L. G. Die thermische Abtoetung von sporen von Bacillus subtilis var. niger ATCC 9372 gas Gasphasen mit liner Wasseraktivitaet < 1,0. Lebensmittel Wissenchaft und Technologie, v. 7, p. 29-33,1975 b.

PRADO FILHO, L. G.; KIEFER, P. Versuchsanlage zur thermischen Behandlung von Bakteriensporen in Gasen mit liner Wasseraktivitaet $<1,0$. Lebbensmittel Wissenchaft und Technologie, v. 7, p. $255-6,1974$.

PRADO FILHO, L. G. Resistência de esporos de Bacillus subtilis var. niger ATCC 9372 ao tratamento por vapor superaquecido. Montagem de equipamento específico e ensaios. Piracicaba, 1982. 124 p.( Livre Docência - Escola Superior de Agricultura “ Luiz de Queiroz"/ USP ).

PRADO FILHO, L. G. Resistência de térmica de microrganismos em ambiente de baixa atividade de água I. Montagem de equipamento específico e calculos termodinâmicos. Ciência e Tecnologia de Alimentos, v. 7, p. $27-49,1987$ a. 
PRADO FILHO, L. G. Resistência térmica de microrganismos em ambiente de atividade de água. II . Resistência térmica de esporos de Bacillus subtilis var. niger frente a vapor superaquecido. Ciência e Tecnologia de Alimentos, v. 7, p. 145 - 71, 1987 b.

PRADO FILHO, L.G. Projeto e construção de câmara de tratamento térmico de esporos de microrganismos. Ciência e Tecnologia de Alimentos, Campinas v.14. n.1. p. 96 104. Jan / Jun. 1994.

PRADO FILHO, L.G. ; GRISOTTO, R.; TAPIA TAPIA, D.M. Resistência térmica de esporos de Bacillus subtilis var. niger ATCC 9372 tratados com vapor superaquecido com atividade de água menor que 1,0. Ciência e Tecnologia de Alimentos, Campinas, v. 16. n.2 p.153-157 Jul/Set. 1996.

PULEO, J. R.; BERGSTROM, S. L.; PEELER, J. T.; OXBORROW, G. S. Thermal resistance of naturally occurring airbone bacterial spores.Applied Microbiology, v. 36, p. $473-9,1978$.

PULEO, J. R. ; FAVERO, M. S.; OXBORROW, G. S.; HERRING, C. M. Method for collecting naturally occurring airbone bacterial spores for determining their thermal resistance. Applied Microbiology, v. 30, p. $786: 90,1975$.

QUAST, D. G.; LEITÃO, M .F. F.; KATO, K.Death of Bacillus stearothermophilus 1518 spore on covers exposed to superheated steam in dole asseptic canning system . Lebensmittel - Wissenchaft und Technologie, v. 10, p. 198 - 2021977.

RANK, E. \& PFLUG, I. J. Dry heat destruction os spores on metal surface and on potatoes during baking. Journal of Food Protection , v. 40, p. 608 - 13, 1977.

REYES, A. L.; CRAWFORD, R. G.; WEHBY, A. J.; PEELER, J. T.; WIMSATT, J. C.; CAMPBELL, J. E.; TWEDT, R. M. Heat resistance of Bacillus spores at various relative humidities. Applied and Environmental Microbiology , v. 42, n. 4 , p. $692-7,1981$.

REYNOLDS, M. C.; LINDELL, K. F.; DAVID, T. J.; FAVERO M. S. BOND, W. W. Thermoradiation inativation of anturally occurring spores in soil. Applied Microbilogy, v. 28, p. $406-10,1974$.

ROEMER, G. B. Heissluftsterilisation. Deutsche Medinizche Wodiens chift. v.100 p. $709-10,1975$. 
RUSSEL, A.D.; HUGO, W.B.; AYLIFE, G.A.T. Heat sterilization. Heat sterilization. In: Principles and practice of desinfection, preservation and sterilization. London: Blackwell Scientific, 1992. cap. 18, p. 483 - 511.

SCHOELEFIELD, J; ABDELGADIR, A. M. Heat resistance characteristic of spores of rough and smooth variants of Bacillus stearothermophilus. In: INTERNATIONAL CONGRESS OF FOOD SCIENCE AND TECHNOLOGY, 4, Valencia, 1974. Proceedings . Madrid, Instituto de Agroquímica y Tecnología de Alimentos c/ Jaime Roig, 1974. V.3, p.71- 8 .

SHARPE, $\mathrm{K}$; BEKTASH, R.M. Heterogenety and modelling of bacterial spores death, the case continuos decreasing death rate. Canadian journal Microbiology, Ottawa, v. 23, p. $1501-1507,1977$.

SHULL, J. J.; CARGO, G.T.; ERNST, R.R. Kinetics of heat activation and themal death of bacterial spores. Applied Microbiology, v. 11, p. $485-7,1963$.

SRIMANI, B.; LONCIN, M. Determination of decimal reduction time of Bacillus subtilis spores at $100{ }^{\circ} \mathrm{C}$. Lebbensmittel - Wissenchaft und Technologie, v. 13 p. $190-2,1980$.

SRIMANI, B.; STAHL , R.; LONCIN, M. Death rate of bacterial spores at high temperetures. Lebensmittel - Wissenchaft und Technologie, v. 13, p. $186-9$, 1980

STUMBO, C. R. Thermobacteriology in food processing . 2 ed., Academic Press 1973.

TODA, K. Studies on heat sterilization . V III- Complex reaction model for heat inactivation of bacterial spores. Journal of Fermentation Technology. v. 48, p.811 $-18,1970$.

VASZ, K ; PROSZT, G. Observation on heat destruction of spores of Bacillus cereus Journal of Applied Bacteriology, v. 21, n 3, p. $431-41,1957$

VON SCHELHORN, M. L. \& HEISS, R. Influence of relative humidity on the thermal resistance of mould spores. In: DUCKWORTH, R. B., ed. Water Relation of Food, Academic Press, 1975. 